\title{
Creativity and Culture in Copyright Theory
}

Julie E. Cohen

Georgetown University Law Center, jec@law.georgetown.edu

This work, copyright 2007 by Julie E. Cohen, was originally published in the UC Davis Law Review, vol. 40, pp. 1151-1205, copyright 2007 by The Regents of the University of California. All rights reserved. Reprinted with permission.

This paper can be downloaded free of charge from:

https://scholarship.law.georgetown.edu/facpub/58

40 U.C. Davis L. Rev. 1151-1205 (2007)

This open-access article is brought to you by the Georgetown Law Library. Posted with permission of the author. Follow this and additional works at: https://scholarship.law.georgetown.edu/facpub

Part of the Intellectual Property Law Commons, and the Law and Economics Commons 


\section{GEORGETOWN LAW Faculty Publications}

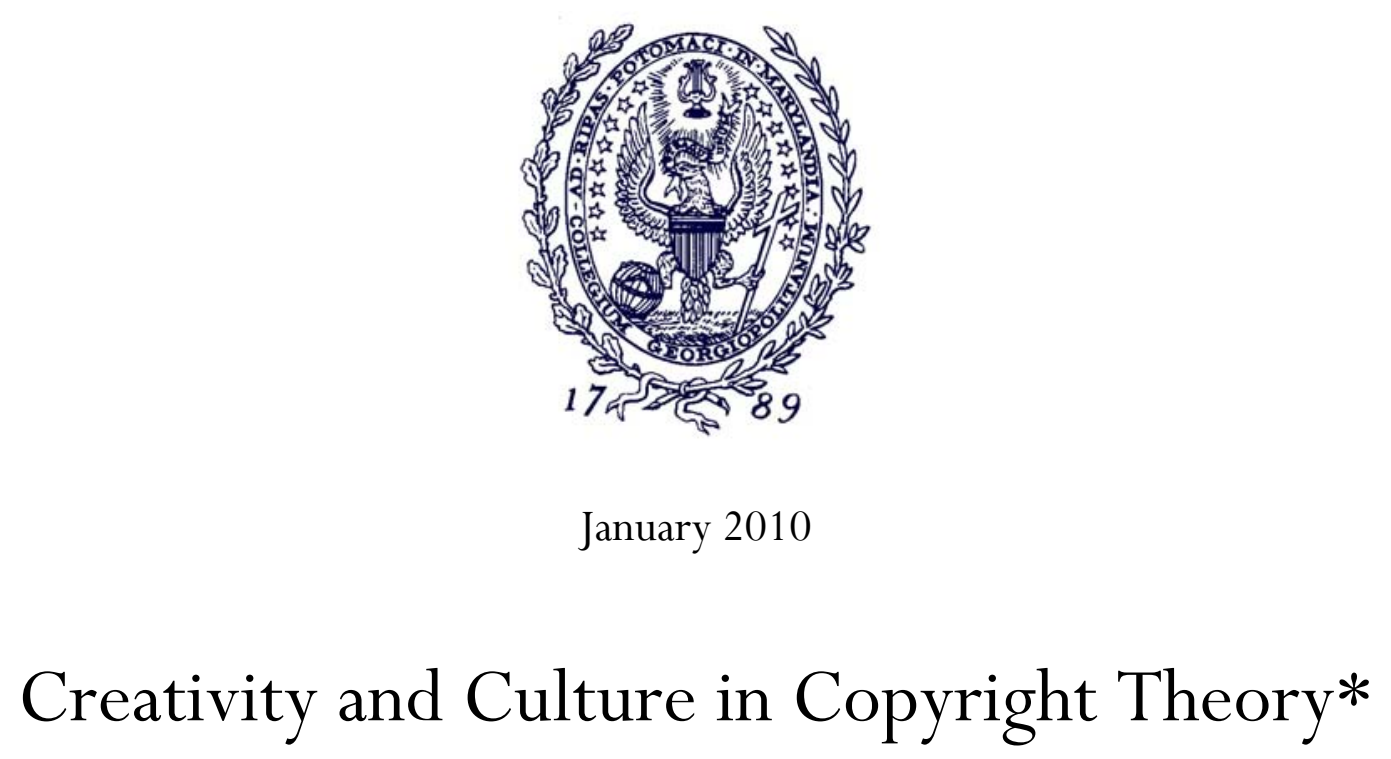

40 U.C. Davis L. Rev. 1151-1205 (2007)

Julie E. Cohen

Professor of Law

Georgetown University Law Center

jec@law.georgetown.edu

This paper can be downloaded without charge from:

Scholarly Commons: http://scholarship.law.georgetown.edu/facpub/58/

SSRN: http://ssrn.com/abstract $=929527$

Posted with permission of the author

*This work, copyright 2007 by Julie E. Cohen, was originally published in the UC Davis Law Review, vol. 40, pp. 1151-1205, copyright 2007 by The Regents of the University of California. All rights reserved. Reprinted with permission. 


\title{
Creativity and Culture in Copyright Theory
}

\author{
Julie E. Cohen *
}

TABLE OF CONTENTS

I. THE CREATIVITY PARADOX.

II. THREE METHODOLOGICAL ANXIETIES .................................. 1154

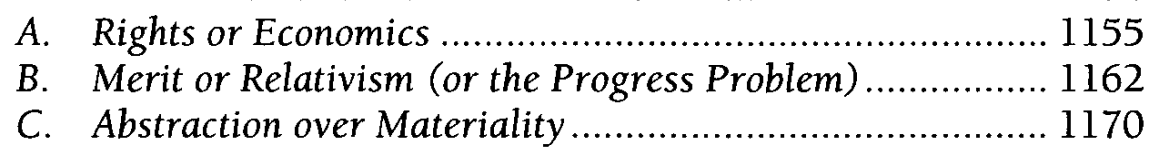

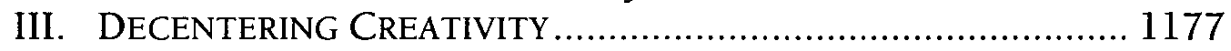

A. Situated Users ......................................................... 1178

B. Networks of Knowledge, Networks of Practice ................. 1183

C. The Play of Culture ................................................. 1190

IV. ENGINEERING CREATIVITY: LAW AND CULTURE...................... 1192

V. COPYRIGHT FOR CREATIVITY: AN EXAMPLE ………................ 1198

\section{The CREativity Paradox}

Creativity is universally agreed to be a good that copyright law should seek to promote, yet copyright scholarship and policymaking have proceeded largely on the basis of assumptions about what it actually is. When asked to discuss the source of their inspiration, individual artists describe a process that is intrinsically ineffable. ${ }^{1}$

\footnotetext{
Professor of Law, Georgetown University Law Center. Thanks to Yochai Benkler, Dan Burk, Margaret Chon, Brett Frischmann, Paul Geller, Andrew Glickman, Emma Jordan, Sonia Katyal, Leslie Kurtz, Mark Lemley, Michael Madison, David McGowan, Naomi Mezey, Susan Scafidi, Richard Schur, Madhavi Sunder, Rebecca Tushnet, Siva Vaidhyanathan, Molly Van Houweling, participants in the Symposium on Intellectual Property and Social Justice, and participants in a faculty workshop at the Georgetown University Law Center for their many helpful comments and suggestions, and to Robert Dowers and Brian Finkelstein for research assistance. Thanks also to Randy Picker and participants on the Picker MobBlog for a very useful discussion of an earlier iteration of the model described in Part III.

1 For both a summary of the literature in this vein and an example of this approach to the creative process, see Roberta Rosenthal Kwall, Inspiration and
} 
Rights theorists of all varieties have generally subscribed to this understanding, describing creativity in terms of an individual liberty whose form remains largely unspecified. ${ }^{2}$ Economic theorists of copyright work from the opposite end of the creative process, seeking to divine the optimal rules for promoting creativity by measuring its marketable byproducts. ${ }^{3}$ But these theorists offer no particular reason to think that marketable byproducts are either an appropriate proxy or an effective stimulus for creativity (as opposed to production), and more typically refuse to engage the question. The upshot is that the more we talk about creativity, the more it disappears from view. At the same time, the mainstream of intellectual property scholarship has persistently overlooked a broad array of social science methodologies that provide both descriptive tools for constructing ethnographies of creative processes and theoretical tools for modeling them.

In Part II of this Article, I argue that the study of creativity has been especially problematic for copyright scholars because it sits at the nexus of three methodological anxieties that copyright scholars experience acutely. The first anxiety has to do with the question whether individual creators or broader societal patterns should be the primary focus of analysis; in intellectual property scholarship, as in

Innovation: The Intrinsic Dimension of the Artistic Soul, 81 NOTRE DAME L. REV. 1945 (2006); see also Justin Hughes, The Personality Interests of Authors and Inventors in Intellectual Property, 16 CARDOZO ARTS \& ENT. L.J. 81 (1998); Russ VerSteeg, Rethinking Originality, 34 WM. \& MARY L. REV. 801, 824-44 (1993).

2 See Justin Hughes, The Philosophy of Intellectual Property, 77 GEO. L.J. 287, 33744 (1988); Neil Weinstock Netanel, Asserting Copyright's Democratic Principles in the Global Arena, 51 VAND. L. REV. 217, 272-76 (1998) [hereinafter Netanel, Global Arenal; Neil Weinstock Netanel, Copyright and a Democratic Civil Society, 106 YALE L.J. 283, 347-62 (1996) [hereinafter Netanel, Democratic Civil Society]; see also Wendy J. Gordon, A Property Right in Self-Expression: Equality and Individualism in the Natural Law of Intellectual Property, 102 YALE L.J. 1533, 1568-72 (1993) (arguing that some works exert "a grip on the mind that only use of the original can shake," and that in such cases Lockean proviso justifies copying by second-comers, but assuming that these cases will be exception rather than rule). I discuss Gordon's more recent work on this problem in Part $V$, infra.

3 See Paul Goldstein, Copyright's Highway: From Gutenberg to the Celestial Jukebox 200-01 (2d ed. 2003); William M. LANDES \& Richard A. Posner, The ECONOMic Structure of Intellectual Property LaW 37-84 (2003); Mark A. Lemley, The Economics of Improvement in Intellectual Property Law, 75 TEX. L. REV. 989, 9931000 (1997) [hereinafter Lemley, Economics of Improvement]; Mark A. Lemley, Property, Intellectual Property, and Free Riding, 83 TEX. L. REV. 1031, 1031 (2005) [hereinafter Lemley, Free Riding]; R. Polk Wagner, Information Wants to Be Free: Intellectual Property and the Mythologies of Control, 103 COLUM. L. REV. 995, 1001-03 (2003); Christopher S. Yoo, Copyright and Product Differentiation, 79 N.Y.U. L. REV. 212, 214-19 (2004). 
legal scholarship more generally, this anxiety is experienced in the form of a required precommitment either to rights-based theories or to economic analysis. The second anxiety has to do with the appropriate metric for evaluating creative output, and is experienced in the form of a required precommitment either to a linear, modernist vision of creative and cultural progress or to an oppositional stance that rejects notions of progress, artistic merit, and authorial will entirely. The third anxiety concerns the relative value of abstract and concrete components of artistic and intellectual culture, and is experienced in the form of a required precommitment to abstraction - to the paramount importance of the idea and the transcendent accessibility of the public domain - that crosses otherwise rigid philosophical divides.

Each of these methodological anxieties is predicated on a false binary, but when rights-based theories and economic analysis together are thought to define the universe of acceptable theoretical approaches this artificiality is astonishingly hard to see. For all their differences, rights theories and economic theories of copyright share a set of firstorder methodological commitments that foreclose other, potentially more fruitful approaches to the interactions between copyright, creativity, and culture. Questioning those commitments opens the way for approaches that enable both a more complex consequentialism and a more concrete specification of the rights that should attend participation in creative processes. These approaches in turn point toward a more sustained engagement with the social science literatures that legal scholars have largely ignored.

The balance of the Article seeks to put these insights to use. In Part III, I sketch a model of creative processes as complex, decentered, and emergent. Within this model, it is neither individual creators nor social and cultural patterns that produce artistic and intellectual culture, but rather the dynamic interactions between them. ${ }^{4}$ The artistic and intellectual value that emerges from these interactions is

\footnotetext{
4 As will become apparent, contemporary social and cultural theorists adopt different approaches to the question of "culture," and my intent here is not to endorse any particular definition, but rather to pursue common threads. Within all of those approaches, however, culture is broader than the universe of artistic and intellectual activities with which copyright is concerned. I will use the terms "artistic and intellectual culture" and "artistic culture" to denote the latter subset of activities. "Creativity" is another concept that extends well beyond the traditional domain of copyright. See, e.g., HOWARD GARDNER, CREATING MindS: AN ANATOMY OF CREATIVITY SeEn Through the Lives of Freud, Einstein, Picasso, Stravinsky, Eliot, Graham, and GANDHI (1993) (exploring creativity in art, science, and social activism). Here, however, I will be concerned principally with ways of understanding creativity in the context of artistic and intellectual culture.
} 
simultaneously real and contingent; it is possible to say both that particular outputs represent valuable additions to collective culture and that their value is determined by underlying knowledge systems that are historically and culturally situated. Like other cultural processes, artistic and intellectual processes are substantially and importantly shaped by the concrete particulars of expression, the material attributes of artifacts embodying copyrighted works, and the spatial distribution of cultural resources. Within a given network of social and cultural relations, an important and undertheorized determinant of creative ferment is the play, or freedom of movement, that the network affords.

Part IV considers the implications of this model for copyright lawmaking and policy analysis. Opponents of "copyright maximalism" have sought to characterize copyright as an intervention into the "information ecology" that can work both good and harm. A more skeptical stance toward the methodological commitments of conventional copyright analysis makes it easier to see (and explain) why. Those commitments tend to produce both an inflated notion of copyright's role in stimulating creativity and an insufficiently keen appreciation of the harms that overly broad copyright can cause. Decentering creativity, by contrast, tends to foster both a more modest conception of copyright's role in stimulating creativity and a keener appreciation of copyright's downside risks. It also fosters a clearer understanding of the connections between copyright, cultural progress, and social justice. Contrary to popular perception, this approach does not necessarily lead to the conclusion that copyright is harmful per se; to adopt it is not, therefore, to be "against copyright." It does, however, suggest some essential doctrinal and policy adjustments, which Part V illustrates.

\section{THREE METHODOLOGICAL ANXIETIES}

Copyright theory and jurisprudence are powerfully structured by a set of interlinked anxieties about the appropriate tools for understanding the interactions between copyright and culture. Those anxieties, which concern the justification for assigning rights, the nature of the progress that copyright is meant to promote, and the mechanics of creative processes, spring from a set of first-order methodological commitments associated with liberal political theory. They define the boundaries of copyright's epistemological universe in a way that excludes many other approaches to investigating and theorizing about creative processes. The result is that despite the voluminous amount of copyright scholarship now being published, 
copyright theory remains impoverished in important and outcomedetermining ways.

\section{A. Rights or Economics}

Within the mainstream of copyright scholarship it has been taken as self-evident that a grand theory of the field must be grounded either in a theory of rights or in a theory of economic analysis. Some rights theorists seek to derive the basis for copyright from the philosophy of property rights; others prefer a vision of copyright grounded in principles of expressive liberty and deliberative democracy. Economic theorists vie with one another to discover new disciplinary sub-strands within economics that might cause the shapes of demand curves to shift, or alter the payout matrices in game theory tables. Proponents of these approaches vigorously debate among themselves whether one approach or the other is superior. I do not intend to take sides in that debate, but rather to challenge the implicit requirement of precommitment to one side or the other. The rights-economics binary elides another sort of consequentialism, which has room within it for a more complex and productive approach to the specification of rights.

The rights-economics binary within copyright theory maps neatly to the classic divide in social and cultural theory between theories concerned primarily with accounts of individual agency and those concerned primarily with accounts of social ordering. Consistent with Kant's categorical imperative, rights theorists focus predominantly on specifying, via logical derivation, the sort of treatment that individuals (whether authors or users) should have a right to expect from a copyright regime. Economic theorists, meanwhile, profess themselves to be concerned primarily with overall efficiency in the production and distribution of social resources, and with factors that might produce distortions from the optimum production and distribution.

As one might expect, the question whether creativity is produced largely from within or stimulated predominantly from without is a good question only if the answer must be one or the other. In recent decades, social and cultural theory have sought to move beyond the self-society divide by articulating approaches that emphasize the evolving, emergent relations between the two. In the main, copyright scholarship has not kept pace with these developments. For the most part, copyright scholars persistently overlook other (nonphilosophical, non-economic) literatures that study artistic and intellectual cultures as phenomena that emerge at the intersections 
between self and society. ${ }^{5}$ As a result, they tend to ignore wellestablished humanities and social science methodologies that are available for investigating the origins of artistic and cultural innovation. These methodologies are diverse but share a number of common attributes. They prize empiricism above logical derivation from so-called first principles, and the forms of empiricism that are prized most highly tend to be ethnographic rather than quantitative. They generate theoretical models of social and cultural processes that are both rigorous and complex, and that tend not to be amenable to mathematical reduction. They recognize that because cultural practices and institutions are evolving and endogenously constituted, scholars wishing to understand them must pay careful attention not only to the forces of rational self-interest but also to practices of rhetoric, representation, and classification. Finally, they emphasize the importance of the material realities of everyday practice.

Why do both rights theorists and economic theorists of copyright assume shared primacy, and why do they tend to find literatures and methodologies that focus on the interactions between self and culture so uncongenial? One explanation for the primacy of rights theories and economic theories within the copyright literature is that such theories are indispensable prerequisites for constructing overarching normative frameworks. ${ }^{6}$ When pressed on the question of engagement with the particulars of creative processes, scholars of both persuasions sometimes respond that richer descriptive and theoretical models of creativity do not themselves dictate any particular arrangement of legal rules. Deriving such rules requires a theory of the good that we are trying to pursue; that theory, or so we are told, can come only from rights-based theories or from economics. Each side then claims that the other really lacks normative sufficiency. Rights theorists note that economic analysis requires a priori specification of some utility function, while economic theorists observe that rights theorists are equally dependent on unproved and unprovable preconceptions about natural rights. This disagreement, however, reveals broader agreement on the importance of identifying a small set of first principles, encoding first-order normative choices, from which a normatively compelling framework for copyright can then be derived in relatively neutral fashion. The best explanation that I have seen for copyright theorists' aversion to cultural theory likewise highlights an assumption

\footnotetext{
5 As Part II.B discusses, there are, of course, some notable exceptions.

6 See Lemley, Free Riding, supra note 3, at 1031-32; David McGowan, Copyright Nonconsequentialism, 69 MO. L. REV. 1, 1-5 (2004).
} 
about first principles shared by copyright theorists on both sides of the rights-economics divide: to emphasize the endogenous relationship of self to culture is to introduce a large set of unruly complications that undermine foundational premises about individual autonomy, and that threaten to undo policy analysis entirely. ${ }^{7}$

Taking these explanations together, the purported advantage of rights theories and economic theories is neither precisely that they are normative nor precisely that they are scientific, but that they do normative work in a scientific way. Their normative heft derives from a small number of formal principles and purports to concern questions that are a step or two removed from the particular question of policy to be decided. With respect to copyright in particular, neither rights nor utility functions need be specified directly in terms of the content of culture. These theories manifest a quasi-scientific neutrality as to copyright law that consists precisely in the high degree of abstraction with which they facilitate thinking about processes of cultural transmission. The commitment to first-order principles of neutrality and abstraction helps to explain copyright scholars' aversion to the complexities of cultural theory, which persistently violates those principles. ${ }^{8}$ It is instructive to contrast that aversion with the current vogue for "complex systems" theories drawn from the natural sciences. Copyright scholars are increasingly preoccupied with theories that stress naturally occurring properties such as complexity and path-dependence, including the emerging science of networks, evolutionary biology, and the theory of genetic memes. ${ }^{9}$ It is hard to

${ }^{7}$ A particularly nice statement of this problem appears in YOCHAI BENKLER, THE Wealth OF NeTWORKS: HOW SOCIAL PRODUCTION TRANSForms Markets AND FreFdom 278-85 (2006). Unlike many others, Benkler does not duck the problem of culture, but instead tries to work around it by specifying a set of minimal conditions vis-à-vis culture that cohere most closely with the aims of liberal political theory.

8 This hierarchy of value also explains a great deal about intellectual property theorists' traditional disdain for trademark law, which has never fit neatly within any rights-based framework and which requires an economic analysis that is irreducibly self-referential.

9 See J.M. Balkin, Cultural Software: A Theory of Ideology (1998); Thomas F. Cotter, Prolegomenon to a Memetic Theory of Copyright: Comments on Lawrence Lessig's The Creative Commons, 55 Fla. L. REv. 779 (2003); Susan P. Crawford, The Biology of the Broadcast Flag, 25 HASTINGS COMM. \& ENT. L.J. 603, 621-29 (2003); Edward Lee, The Public's Domain: The Evolution of Legal Restraints on the Government's Power to Control Public Access Through Secrecy or Intellectual Property, 55 HAstings L.J. 91, 14247, 170-76 (2003); Daniel F. Spulber \& Christopher S. Yoo, On the Regulation of Networks as Complex Systems: A Graph Theory Approach, 99 Nw. U. L. REv. 1687 (2005); see also BENKLER, supra note 7 (using network science to inform an argument grounded in political theory); Neil Weinstock Netanel, Copyright and "Market Power" 
avoid concluding that these theories are attractive to many scholars because they offer the perceived certainty of scientific law, and therefore enable discussion of cultural complexity and pathdependence in terms that avoid engaging with questions of meaning.

The problem with this approach is that it is too narrow both descriptively and normatively. Let us return to the argument that deriving a normative model of copyright requires a theory of rights or a theory of economics. It is important, first, to understand precisely what this argument claims. For rights theorists, the claim appears to be a relatively straightforward one about the importance of having a deontological political philosophy in which normative arguments can be grounded. In the case of economics, the parallel claim is not nearly as clear. Many practitioners of "law and economics" seem to think that they are doing (social) science as opposed to mere philosophy. But by that measure the argument about the normative superiority of economics is a very odd one. If "economics" is understood to denote a social science methodology, then its normative valence is no greater than that of, say, sociology or anthropology. If the claimed superiority of economics is to have any basis, it must rest on a link to political philosophy that those other disciplines presumptively lack. Within the framework of liberal political philosophy in which legal scholars are trained, the obvious candidate is utilitarianism, and so that is the political philosophy with which law and economics has become identified.

The contention, then, is that even if rights-based theories and utilitarian theories are lacking in descriptive power, together they cover the normative waterfront. Within economic reasoning, this move operates as a naked form of intellectual irredentism, which holds both that any consequentialist theory of the good must be amenable to reformulation in the language of economics and that a judicious sprinkling of economically derived jargon is sufficient to effectuate the reformulation. Here the linked anxieties about neutrality and abstraction come bubbling to the surface; the idea seems to be that utilitarian analysis is the prototype case of consequentialism, ${ }^{10}$ a position which it claims both by virtue of its high degree of abstraction and its ability to define away problems of judgment. Rights theorists subscribe to these assumptions largely out of disinterest in and

in the Marketplace of Ideas, in ANTITRUST, PATENTS AND COPYRIGHT 149 (François Lévêque \& Howard Shelanski eds., 2005) (using network science to inform an argument grounded in First Amendment theory).

10 On prototypes, see GeORGE LAKOFF, WOMEN, Fire, and Dangerous THINGS: What CATEgories ReVEal ABOUT the Mind 40-54 (1987). 
dissatisfaction with consequentialist reasoning generally; for rights theorists, all consequentialist theories are normatively indeterminate. But the underlying assumption (on both sides) that any consequentialist theory must be grounded in economics is false. The universe of consequentialist theories is not coextensive with the universe of utilitarian ones.

In particular, the tendency to conflate consequentialism with utilitarianism ignores versions of consequentialism that use rules other than utility maximization to decide on good outcomes. Rule consequentialism enables formulation of instrumental goals without imposing the artificial constraint that the resulting improvements in human well-being be amenable to expression in terms of utility, and therefore perfectly or even approximately commensurable. And it enables the discussion and definition of the rights that human beings should be entitled to expect without imposing the artificial constraint that those rights be logically derivable from a small handful of first principles.

Among the various versions of nonutilitarian or rule consequentialism, I would like to focus on the capabilities approach developed by Martha Nussbaum and Amartya Sen. " This approach takes as its lodestar the fulfillment of human freedom, and defines freedom in terms of the development of affirmative capabilities for flourishing. Thus defined, freedom is not simply a function of the absence of restraint, but also depends critically on access to resources and on the availability of a sufficient variety of real opportunities. ${ }^{12}$ Because of these requirements, freedom and equality are integrally connected within the capabilities approach. Equality is not simply a matter of making distributive adjustments here and there once the basic structure of entitlements is decided according to some other set of criteria. Substantive equality is a fundamental concern and a normative constraint on both rule structures and policy recommendations. ${ }^{13}$ Within the literature on copyright theory there is

11 See generally amartya Sen, Development as Freedom (1999) [hereinafter Sen, Development]; Amartya Sen, Inequality ReEXAmined (1992) [hereinafter Sen, INEQUALITY]; Martha C. Nussbaum, Aristotelian Social Democracy, in LIBERALISM AND THE GOOD 203 (R. Bruce Douglass et al. eds., 1990); Amartya Sen, Elements of a Theory of Human Rights, 32 PHIL. \& PUB. AfF. 315 (2004) [hereinafter Sen, Elements]; Human Development and Capability Association, http://www.capabilityapproach.com/ Home.php (last visited Feb. 8, 2007).

12 See SEN, DeVelopMENT, supra note 11, at 70-85; Nussbaum, supra note 11 , at 228-34; Sen, Elements, supra note 11, at 330-36.

13 See SEN, DEVELOPMENT, supra note 11, at 87-110; SEN, INEQUALITY, supra note 11 , at 21-26. 
evidence of a recent turn toward explicit adoption of the capabilities approach. Leading works include Yochai Benkler's treatment of the linkages between information policy, information markets, and human freedom; Margaret Chon's work on intellectual property and development; and Madhavi Sunder's exploration of the intersections between intellectual property, the Internet protocol, and identity politics. ${ }^{14}$ The theories advanced by these scholars differ in many respects, but are consistent in their commitment to at least the principles just described.

Consequentialism in this vein diverges from the prevailing modes of theorizing about copyright and its relation to cultural policy in four important respects. First, it holds normative commitments closer to the surface, and consequently more available for interrogation. In this it compares favorably with economic theories, which tend to skip over the task of specifying initial utility functions. Second, the capabilities approach resists abstraction from the conditions of everyday life, and demands instead that claimed rights be defined to include the conditions necessary for real people to take full advantage of them. It therefore both demands resort to and provides a clear point of entry for the messy social science methodologies described above. Third, the capabilities approach embraces complexity and ambiguity; it does not expect resolution of large policy questions to be easy. ${ }^{15}$ Accordingly, it is more capable of encompassing and articulating a framework for resolving the competing claims of incommensurable goods, and for that reason it is especially well suited to theorizing about rights in culture. Finally, because it emphasizes substantive equality as a condition of human freedom, the capabilities approach is especially well suited to theorizing about the linkages between rights, enabling conditions, and social justice.

14 BENKLER, supra note 7; Margaret Chon, Intellectual Property and the Development Divide, 27 Cardozo L. Rev. 2821 (2006); Madhavi Sunder, IP3 3 , 59 Stan. L. Rev. 257 (2006); see also MARGaret JANe RADiN, CONTESTEd COMMOdities 54-78 (1996) (considering problems in property theory in light of Nussbaum's criteria for human flourishing). In his early work on the fair use doctrine, Terry Fisher advanced a compelling account of the good life, and of copyright's relevance to attaining it, that resembles Nussbaum's later account of "Aristotelian social democracy" in some respects, but then chose to tackle the problem of assigning copyright entitlements against an idealized baseline condition of equal resources. See William W. Fisher III, Reconstructing the Fair Use Doctrine, 101 HaRv. L. Rev. 1659, 1745-66 (1988); see also William W. Fisher III, Property and Contract on the Internet, 73 CHI.-KenT L. Rev. 1203, 1215-18 (1998).

15 See Sen, Elements, supra note 11, at 322-23. 
Application of the capabilities approach to matters of copyright and cultural policy is complicated, however, by other considerations that relate to broader cross-currents in twentieth century intellectual history. Both Sen and Nussbaum are firmly committed to locating the capabilities approach within the evolving traditions of liberal political economy and philosophy. ${ }^{16}$ Benkler likewise situates his work squarely within those traditions. ${ }^{17}$ That formulation, I think, obscures the extent of the intellectual shift that the capabilities approach represents. If this is liberalism, it is a version that salvages the core substantive commitments to individual dignity and well-being at the cost of some equally core methodological commitments. At the very least, then, the fit is imperfect. Exclusive identification with the liberal philosophical tradition also has costs. Nussbaum and Sen, and Benkler to a lesser degree, appear concerned to show that their approaches do not derive from, or require endorsement of, a standardless postmodernism. ${ }^{18}$ Yet (as Part Il.B will discuss) that stance rejects a rather large amount of recent thinking on the question of culture and its relationship to the questions of freedom and equality with which the capabilities approach is centrally concerned.

Chon and Sunder, in contrast, think that a deeper and more rigorous engagement with postmodernist explorations of culture is essential to evaluating the effects of copyright on human flourishing in the way that the capabilities approach requires. Chon seeks to craft a theory of intellectual property rights that is sensitive to postmodernist understandings of the relationships between culture, power, and economic development; Sunder, to craft a theory of intellectual property ownership that is sensitive both to postmodernist understandings of identity and to the postmodernist critique of culture as fixity. Like Chon and Sunder, I think that there is much to be gained from this sort of intellectual hybridization. The perception of "postmodernism" as requiring both a boundless relativism and a deepseated cynicism about human potential is a caricature; strands within

16 See SEN, DeVeloPMENT, supra note 11, at 292-97; SEN, INEQUALITY, supra note 11, at xi; Martha C. Nussbaum, Public Philosophy and International Feminism, 108 ETHICs 762, 770-72 (1998) [hereinafter Nussbaum, Public Philosophy]; Nussbaum, supra note 11 .

17 BENKLER, supra note 7, at 18-20.

18 See Sen, Development, supra note 11, at 247; Nussbaum, Public Philosophy, supra note 16, at 770-73; see also BENKLER, supra note 7, at 279-85 (asserting that liberal political theory must confront culture and advancing account of culture developed from within liberal political theory). 
the emerging postmodernist tradition are deeply humanist. ${ }^{19}$ The intellectual stance that I have in mind, and that I take Chon's and Sunder's work to represent, is neither strictly liberal nor strictly postmodern, nor is it simply interdisciplinary, since the boundaries it crosses do not divide merely disciplines. ${ }^{20}$ At least as applied to copyright problems, it lends the capabilities approach a richness and a concreteness that this approach otherwise lacks.

\section{B. Merit or Relativism (or the Progress Problem)}

Copyright's stated purpose is to promote progress, but how is it to do this? Both rights theorists and economic theorists are deeply suspicious of the role of value judgments about artistic merit in justifying the recognition and allocation of rights. They have therefore struggled mightily to articulate neutral, process-based models of progress that manage simultaneously to avoid enshrining particular criteria of artistic and intellectual merit and to ensure that the "best" artistic and intellectual outputs will succeed. For the most part, they have refused to engage the critique of this enterprise offered by scholars grounded in postmodernist social and cultural theory, and instead have characterized that critique as advocating a pernicious relativism. Here again, this stance exposes a shared epistemological universe that is relatively narrow, and that forecloses potentially fruitful avenues of inquiry into the processes of cultural production.

The canonical statement of the modernist anxiety about the twin dangers of judgment and relativism is Justice Holmes's warning that:

It would be a dangerous undertaking for persons trained only to the law to constitute themselves final judges of the worth of pictorial illustrations. . . At the one extreme some works of genius would be sure to miss appreciation. Their very novelty would make them repulsive until the public had learned the

19 Both Chon and Sunder are keenly aware of this. David Lange was one of the earliest to note the humanist quality of postmodernist accounts of culture. See David Lange, At Play in the Fields of the Word: Copyright and the Construction of Authorship in the Post-Literate Millennium, LAW \& CONTEMP. ProBs., Spring 1992, at 139 (reading Foucault's essay on author-function as powerful enabler of creative and expressive freedom). Chon and Sunder, however, read postmodernist social and cultural theory as placing relatively greater emphasis on equality as an independent and sometimes countervailing value to the cultural liberty that Lange identified. Chon, supra note 14 , at 2888-2909; Sunder, supra note 14, at 313-21.

20 Keith Aoki would describe this stance as a syncretic one. See Keith Aoki, Distributive and Syncretic Motives in Intellectual Property Law (with Special Reference to Coercion, Agency, and Development), 40 UC DAvIS L. REv. 717, 719 (2007). 
new language in which their author spoke. . . At the other end, copyright would be denied to pictures which appealed to a public less educated than the judge. ${ }^{21}$

On its face, this statement works hard to avoid enshrining particular criteria of artistic and intellectual merit. But it presumes that they exist, and that appropriate judgments will be made by the audiences competent to do so, as long as copyright does not attempt to pick winners in the marketplace of ideas.

In the last two decades, this formulation of copyright's role in facilitating cultural production has come under sustained challenge from scholars grounded in postmodernist social and cultural theory. Peter Jaszi, David Lange, and Martha Woodmansee explored the modernist narrative's implicit dependence upon a vision of the solitary, romantic author, while Margaret Chon interrogated its implicit presumption of linear, teleological progress. ${ }^{22}$ James Boyle $^{2}$ illustrated the ways in which the construct of the romantic author is deployed to legitimate frameworks of economic domination, while Rosemary Coombe sought to rehabilitate those marginalized as passive consumers of the fruits of romantic authorship. ${ }^{23}$ Niva Elkin-Koren extended these critiques into the realm of political theory, offering an

21 Bleistein v. Donaldson Lithographing Co., 188 U.S. 239, $251-52$ (1903).

22 Peter Jaszi, On the Author Effect: Contemporary Copyright and Collective

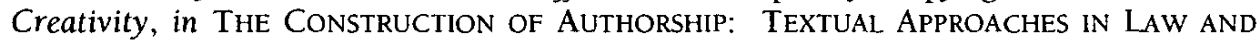
LITERATURE 29 (Martha Woodmansee \& Peter Jaszi eds., 1994); Peter Jaszi, Toward a Theory of Copyright: The Metamorphoses of "Authorship," 1991 DUKE L.J. 455 (1991); Lange, supra note 19; Martha Woodmansee, On the Author Effect: Recovering Collectivity, in THE CONSTRUCTION OF AuthorSHIP, supra, at 14; Martha Woodmansee, The Genius and the Copyright: Economic and Legal Conditions of the Emergence of the "Author," 17 EIGHTEENTH-CENTURY STUd. 425 (1984); Margaret Chon, Postmodern "Progress": Reconsidering the Copyright and Patent Power, 43 DEPAUL L. REV. 97 (1993); see also Robert H. Rotstein, Beyond Metaphor: Copyright Infringement and the Fiction of the Work, 68 CHI.-KENT L. REV. 725 (1993) (critiquing copyright's construct of fixed, autonomous work).

23 James Boyle, Shamans, SoftWare, and SpleEns: LAW and the Construction of the Information Society (1996); Rosemary J. CoOmbe, The Cultural Life of INTEllectual Properties: AUTHORShip, APPROPRIATION, AND LAW 58 (1998); see also SUSAN SCAFIDI, Who OWNS CUlTURE? APPROPRIATION AND AUTHENTICITY IN AMERICAN LAW (2005) (exploring relationships between cultural products and communal identities); Keith Aoki, Adrift in the Intertext: Authorship and Audience "Recoding" Rights - Comment on Robert H. Rotstein, Beyond Metaphor: Copyright Infringement and the Fiction of the Work, 68 CHI.-KENT L. REV. 805 (1993) (considering political implications of postmodernist critique). 
account of "progress" as inhering in widely distributed, participatory acts of social meaning-making. ${ }^{24}$

Rather than treating the postmodernist critique of authorship, originality, and progress as an invitation to inquire more closely into the cultural production of knowledge, copyright theory has tended to marginalize this critique. This process sometimes begins with an act of misclassification, in which the postmodernist critique is identified with "postmodernist literary criticism." ${ }^{25}$ That characterization vastly oversimplifies the range of literatures on which the critique relies. It also ignores the fact that the critique of the modernist model of cultural production includes other strands within the copyright literature, including most notably the important work by Lange and Jessica Litman on the relation of the "public domain" to cultural production and by Michael Madison on the ways in which patterns of social and cultural organization shape prevailing understandings of fair use. ${ }^{26}$ Misclassification is followed by misreading. "Postmodernist literary criticism" (or more generally "postmodernism") is taken as holding that texts have no authors and no meaning whatsoever, and the postmodernist critique of copyright is taken as adopting a similar stance. The allegation that doctrinal overbreadth stifles productive borrowing is taken as stating a claim about the requirements of "postmodern art" (or "appropriation art"), which is assumed to differ in fundamental ways from "art" more generally.

24 Niva Elkin-Koren, Cyberlaw and Social Change: A Democratic Approach to Copyright Law in Cyberspace, 14 CARDOzO ARTS \& ENT. L.J. 215 (1996).

${ }_{25}$ See Jane C. Ginsburg, Authors and Users in Copyright, $45 \mathrm{~J}$. COPYRIGHT SOC'Y U.S.A. 1, 7-8 (1997); Hughes, supra note 1, at 90; Justin Hughes, Size Matters (or Should) in Copyright Law, 74 Fordham L. Rev. 575, 621 (2005); see also Mark A. Lemley, Romantic Authorship and the Rhetoric of Property, 75 TEX. L. REv. 873, 878 n.35 (1997) ("Treating Boyle's book as an exercise in linear logic is perhaps unfair, given its postmodern character.").

26 David Lange, Recognizing the Public Domain, LAW \& CONTEMP. ProBS., Winter 1981, at 147; Jessica Litman, The Public Domain, 39 EMORY L.J. 965 (1990); Michael J. Madison, A Pattem-Oriented Approach to Fair Use, 45 WM. \& MARY L. ReV. 1525 (2004). Lange's and Litman's works are part of the mainstream copyright canon, but their embrace has required a narrow reading of both authors' arguments. Both works tend to be understood as being about what should be "in the public domain," rather than more generally about the nature of creative processes and the ways in which legal categories shape our understanding of those processes. Litman in particular did not position her own work as animated by postmodernist theory, and I am quite certain that she would not describe it that way. Lange's later work on the public domain comes closer to adopting the sort of stance with respect to postmodernism that I am suggesting. See Lange, supra note 19, at 148-51. Madison's work draws eclectically from a number of different literatures. 
Thus characterized, the postmodernist critique of copyright is interpreted as setting up another either/or choice, this time between merit and a pernicious cultural and moral relativism. To avoid relativism, one must choose merit. But this choice creates enormous methodological difficulties of its own. In particular, to avoid the tension that endorsement of a substantive vision of progress would create with principles of value-neutrality and negative liberty, both rights theorists and economic theorists retreat to a process-based vision of merit-based selection. For economic theorists this vision is encapsulated in the maxim de gustibus non est disputandum; for rights theorists, the starting point is the commitment to intellectual and expressive freedom. Both versions presume that, under conditions of fair competition, personal decisions about information consumption will produce results that make sense - that the truest and most beautiful works will be the ones that appeal most strongly to the citizen's deliberative faculty, or to the consumer's enlightened selfinterest. Since it is far from obvious that the real world actually works this way, the turn to process rapidly generates its own anxieties, which revolve around whether the communicative marketplace actually will work as the models predict and what exactly fair competition is.

Here again, surface disagreement between rights theorists and economic theorists conceals broader agreement on first principles. The unspoken and increasingly frantic dialectic between fidelity to and distrust of the marketplace model of communication that animates so much of copyright theory is premised on a first-order commitment to a rationalist philosophy that conceives of knowledge as transcendent and absolute, rather than contingent and evolving. Both rights-based theories and economic analysis are deeply rooted in Anglo American liberal political philosophy, which in turn sits within a tradition of Enlightenment rationalism extending from Kant to Weber to Habermas and Rawls. Whatever their internal disagreements, works within this tradition presume the existence of truths amenable to rational discourse and deliberation. They disagree chiefly on comparatively trifling questions about which market signals are accurate and which are mere distortions.

But deeper engagement with "postmodernist" social and cultural theory need not lead to the debilitating relativism that copyright scholars fear. These literatures are better understood as opening the way for an account of the nature and development of knowledge that is both far more robust and far more nuanced than anything that liberal political philosophy has to offer. This account seeks to understand how existing knowledge systems have evolved, and how they are encoded and enforced. It explores the dialectic between 
settled truths and disruptive upheavals, and seeks to illumine the ways in which particular innovations become accepted as truth or enshrined as artistically valid. This is not to suggest that social and cultural theorists offer a single account of "culture"; to the contrary, questions about the nature and origins of culture and the patterns of cultural change are hotly debated. ${ }^{27}$ What these literatures offer is something far more valuable: a toolkit for exploring questions about culture in ways that liberal political philosophy does not allow. And that toolkit is an indispensable prerequisite for understanding and evaluating the cultural work that a system of copyright does.

Social and cultural theories that emphasize the contingent, iterative, and performative development of knowledge are rooted in several philosophical traditions that liberalism has resisted, and of which copyright scholars have remained largely skeptical. One tradition that is particularly useful for studying a legal regime meant to promote artistic and intellectual progress extends from Nietzsche through Heidegger and Foucault to a number of contemporary cultural theorists, and emphasizes the social construction of systems of knowledge. Social theory in this tradition seeks to understand the evolution of systems of knowledge and the ways in which knowledge both undergirds and is shaped by assertions of power. ${ }^{28}$ Another tradition extends from Marx through the Frankfurt School of cultural theory, and applies Marxist principles of political economy to the analysis of culture. ${ }^{29}$ A third tradition is broadly phenomenological; it

27 For a useful overview, see generally TERRY EAGLETON, THE IDEA OF CULTURE (2000). Eagleton views "culture" as encompassing most of the binary definitions within which others have sought to contain it.

28 For some of the leading approaches, see generally PIERRE BOURDIEU, THE FIELD of Cultural Production (1993) [hereinafter Bourdieu, Cultural Production]; Pierre Bourdieu, Practical Reason: ON the Theory of Action 3-13 (1998); Michel Foucault, AN ARCHAEOlogy OF KNOWLEdge 21-70 (1972); Michel Foucault, Discipline AND PUNiSH: THE BIRTH OF THE PRISON 135-228 (Alan Sheridan trans., 1977); ANTHONY GIDDENS, THE CONSTITUTION OF SOCIETY: OUTLINE OF THE THEORY OF STRUCTURATION (1984). Heidegger responded to the indeterminacy of knowledge by positing the existence of, and arguing for fidelity to, a pre-technical essence of being. See MARTIN HEIDEgGer, The Question Concerning Technology, in BASIC WRITINGS 307 (David Farrell Krell ed., 2d ed. 1993). This approach has been justly criticized for falling into many of the same errors as natural rights thinking.

${ }_{29}$ See Theodor Adorno \& Max Horkheimer, The Culture Industry: Enlightenment as Mass Deception, in The Cultural Studies Reader 29 (Simon During ed., 1993); Antonio Gramsci, The Intellectuals, in SELECTIONS FROM THE PRISON NOTEBOOKS 5-23 (Quintin Hoare \& Geoffrey Nowell Smith trans., 1971); cf. BENKLER, supra note 7, at 280-81 (considering lessons that liberal tradition might derive from Gramsci's theory of cultural hegemony). 
interrogates the origins of cognition and perception, and explores the limits of language as a means of representation. Some useful strands within this tradition include Thomas Kuhn's study of the evolution of scientific knowledge, ${ }^{30}$ work by sociologists and anthropologists such as Clifford Geertz and Erving Goffman that analyzes culture as a process enacted by its participants, ${ }^{31}$ and research by cognitive theorists that advances a model of human cognition and communication as embodied and spatially situated. ${ }^{32}$ In different ways, each of these approaches seeks to understand how culture emerges from perception, practice, and discourse.

Perhaps the most important point that tends to be overlooked by copyright scholars (and legal scholars more generally) is that none of these literatures has as its stated purpose the "trashing" of "conventional wisdom." To the contrary, all of the theoreticians mentioned above have recognized and acknowledged that shared premises generating predictable rhythms are essential to the operation of a functioning society. In this their work is distinct from more textually oriented postmodernist thought that emphasizes the radical indeterminacy of the sign. It bears emphasizing that postmodernist thought is not monolithic, and deconstruction is not its core enterprise. Postmodernist literary theory and art criticism are disciplines that focus narrowly on the interpretation of texts; equating these disciplines with postmodernist social and cultural theory more generally is a mistake. But the same copyright scholars who can generate lengthy disquisitions on the distinctions between Locke and Mill, or Habermas and Rawls, or Demsetz and Arrow have tended to

30 Thomas S. Kuhn, The Structure of SCientific Revolutions (2d ed. 1970).

31 See Clifford Geertz, Thick Description: Toward an Interpretive Theory of Culture, in The Interpretation of Cultures 3 (1973); Erving Goffman, The Presentation of SELF IN EVERYDAY LIFE (1959).

32 See generally GeORGe Lakoff \& Mark Johnson, Philosophy in the Flesh: THE EmbodiEd Mind and Its Challenge to Western Thought (1999) [hereinafter Lakoff $\&$ JOHNSON, PHILOSOPHY IN THE Flesh]; GeORGE LAKOFF \& MARK JOHNSON, METAPHORS WE LIVE BY (1980). Lakoff and Johnson note that their challenge to analytic philosophy echoes earlier challenges issued by John Dewey, who advocated interrogation of the constitutive roles of habit, custom, and embodied experience, and by Maurice Merleau-Ponty, who argued that human perception and thought are fundamentally embodied. See LAKOFF \& JOHNSON, PHILOSOPHY IN THE FLESH, supra, at 97. See generally John Dewey, Experience and Nature (1925); John DeWEy, Human NATURE AND CONDUCT (1922); JohN DEWEY, THE INFLUENCE OF DARWIN ON PHILOSOPHY (1910); Maurice Merleau-Ponty, The Essentlal Writings OF Merleau-PonTy 47-80, 138-81 (Alden L. Fisher ed., 1969); Maurice Merleau-Ponty, Phenomenology of PERCEPTION (Colin Smith trans., 1962). 
lump all things "postmodernist" together and equate them with nihilism.

Instead, within each of these scholarly approaches what is most important is that settled modes of knowing not become entrenched and calcified. This concern resonates deeply with copyright law's imperative to foster progress, but demands two important modifications to the conventional understanding of that imperative. First, it requires that "progress" be assigned a more open-ended interpretation. Stripped of its association with modernist teleologies, progress consists, simply, in that which causes knowledge systems to come under challenge and sometimes to shift. Second, and precisely because the postmodernist understanding of progress abandons the comforting fiction of modernist teleologies, a postmodernist approach to knowledge demands careful attention to social, cultural, and legal mechanisms for evaluating, rewarding, and internalizing progress. Recognizing that those mechanisms are always already normatively compromised, it directs our attention to the value judgments that they enact. It thereby foregrounds the complex linkages between and among progress, power, and participation.

It is unsurprising, then, that these scholarly approaches have produced many of the works that have become foundational to the study of the creative and intellectual processes, practices, and institutions that we call "science" and "art." On the scientific side, perhaps the foremost of these is Kuhn's study of the development of scientific knowledge, and in particular the distinction that Kuhn developed between "normal science" and a "paradigm shift" in generally accepted scientific understanding. ${ }^{33}$ More recently, the umbrella field known as science and technology studies ("STS") has sought to illuminate the social construction of both scientific knowledge and technical artifacts using the tools of social and cultural theory. ${ }^{34}$ On the "artistic" side of the ledger, important works include Foucault's exploration of the ways in which the modern construct of "authorship" structures public discourse about creativity, authenticity,

\footnotetext{
33 See KUHN, supra note 30 , at 23-51.

34 For some leading examples of this approach, see generally WIEBE E. BIJKER, OF BiCYCles, BAKELITES, AND BulBS: TOWARD a THEORY OF SOCIOTECHNICAL CHANGE (1995); Donna J. Haraway, Simians, Cyborgs, and Women: The Reinvention of Nature (1991); Bruno latour, The Pasteurisation of France (Alan Sheridan \& John Law trans., 1988); THE Social CONSTRUCtION OF TeCHNOlogical SySTEMS (Wiebe E. Bijker et al. eds., 1987); A Sociology of MONSTERS: Essays ON POWER, TeChNOlOGy AND DOMination (John Law ed., 1991).
} 
and meaning; ${ }^{35}$ writings by feminist literary theorists like Laurie Finke and Mary O'Connor, who have sought to relocate authorship within an ongoing process of dialogue; ${ }^{36}$ Pierre Bourdieu's and Howard Becker's explorations of the ways in which expertise and authority shape cultural production; ${ }^{37}$ and Walter Benjamin's meditation on reproduction of cultural artifacts and control of cultural meaning. ${ }^{38}$ They include, as well, the work of a number of cultural and media theorists who have sought to trace the effects of mass culture on the construction of cultural identities and to probe the ways in which cultural identities shape relations between self and community. ${ }^{39}$ Finally, scholars from a variety of disciplines have sought to understand creativity across the art-science divide. Researchers in psychology and education have produced a vibrant literature on the social, cultural, and psychological factors that shape creativity, while philosophers as disparate as John Dewey, Nelson Goodman, and Jacob Bronowski have explored the phenomenology of creativity in a more holistic fashion. ${ }^{40}$

Copyright theorists should be centrally concerned with works such as these, which probe processes of cultural production and cultural

35 Michel Foucault, What Is an Author?, in LANGUAGE, COUNTER-MEMORY, Practice: Selected Essays and Interviews 113 (Donald F. Bouchard ed., Donald F. Bouchard \& Sherry Simon trans., 1977).

36 See generally LAURIE Finke, FEminist TheORY, WOMEN's Writing (1992); Mary O'Connor, Subject, Voice, and Women in Some Contemporary Black American Women's Writing, in FEMINISM, BAKHTIN, AND the DialogiC 199 (Dale M. Bauer \& Susan Jaret McKinstry eds., 1991); Carys J. Craig, Reconstructing the Author-Self: Some Feminist Lessons for Copyright Law, 15 J. GENDER, SOC. POL'Y \& LAW (forthcoming 2007).

37 Howard S. Becker, Art Worlds (1982); Bourdieu, Cultural Production, supra note 28.

38 Walter Benjamin, The Work of Art in the Age of Mechanical Reproduction, in ILluMiNATIONS 219 (Hannah Arendt ed., 1968).

39 Leading examples include ARJUN APPADURAI, MODERNITY AT LARGE: CULTURAL Dimensions of Globalization (1996); John Fiske, Television Culture (1987); Stuart Hall, Encoding/Decoding, in The Cultural Studies ReAder 507 (Simon During ed., 2nd ed. 1993); see also Sunder, supra note 14; Madhavi Sunder, Intellectual Property and Identity Politics: Playing with Fire, 4 J. GENDER RACE \& JUST. 69 (2000) [hereinafter Sunder, Identity Politics].

40 On the psychology of creativity, see generally TERESA M. AMABILE, CREATIVITY IN Context (1996); Mihaly Csikszentmihalyi, Creativity: Flow and the Psychology of DISCOVERY AND INVENTION (1996); GARDNER, supra note 4; THE INTERNATIONAL HANDBOOK OF CREATIVITY (James C. Kaufman \& Robert S. Sternberg eds., 2006); DEAN KeIth Simonton, Origins of GeniUS: DARWINIAN PERSPECTIVES ON CREATIVITY (1999). On the phenomenology of creativity, see generally JACOB BRONOWSKI, THE ORIGINS OF KNOWLEDGE and IMAGINATION (1978); JOHN DEWEy, ART AS EXPERIENCE (1934); Nelson GOODMAN, WAYS OF WORLDMAKING (1978). 
change from a variety of empirical and theoretical angles. Here, however, another difficulty typically arises. Careful exploration of these topics requires confronting not only preconceptions about progress, but also preconceptions about creative processes and practices. Copyright theorists of all persuasions tend to envision these processes as exercises in abstraction. The commitment to abstraction powerfully shapes the legal understanding of the ways that creative practitioners work and the resources that they require.

\section{Abstraction over Materiality}

A legal regime meant to promote progress requires a set of premises about the ways in which progress develops. The reasons for assigning rights, the specification of rights, and the resolution of particular disputes all presuppose and reproduce particular understandings of creative processes and practices. Here we come to the third methodological anxiety, which concerns the relative value of abstract and concrete components of artistic and intellectual culture (and which relies on an assumption, implicit in this privileging, that the two can be neatly distinguished). Both rights theorists and economic theorists articulate a vision of copyright, and of cultural progress, within which abstraction is prized highly, and in which the most valuable aspects of artistic and intellectual culture are those that are most amenable to abstraction. What $\mathrm{l}$ want to describe here is a process analogous to what Katherine Hayles characterizes as the "platonic backhand," which "constitute[s] the abstraction as the originary form from which the world's multiplicity derives," followed by the "platonic forehand," which derives from the foundational abstraction "a multiplicity sufficiently complex that it can be seen as a world of its own." copyright theory constructs a model of creative practice that obviates any need to interrogate creative practice more directly.

The foundational abstraction within copyright discourse concerns the primacy of idea over expression. As every student in the basic copyright course learns, copyright does not protect "ideas," and that is because ideas are thought to be the shared raw material of progress. Ideas, in other words, are what enable subsequent authors to build on the works of past authors even if the expression in those works is the subject of exclusive rights. ${ }^{42}$

41 N. Katherine hayles, how We Became posthuman: Virtual bodies in CYBERNETICS, LITERATURE, AND INFORMATICS 12-13 (1999).

42 See Eldred v. Ashcroft, 537 U.S. 186, 219 (2003); Harper \& Row Publishers, 
Over time, the idea-expression distinction has come to encode a theory of cultural transmission that is unique to copyright. Both copyright scholars and cultural theorists understand cultural texts (including both conventional literary texts and all other forms of artistic expression) as performing a cultural transmission function. Within cultural theory, that function resides in the text itself, including both "idea" and "expression"; for the most part, indeed, cultural theory does not draw this distinction at all. Cultural theorists hold that texts reflect context-dependent meanings rather than invariant "ideas," and regard text and meaning as both inseparably intertwined and continually evolving. ${ }^{43}$ Within copyright theory, however, the cultural transmission function performed by artistic and intellectual works is presumed to reside principally in the "ideas" conveyed by such works rather than in the particular form of their expression. Broad agreement as to this basic proposition extends across the methodological divide. To the extent that both rights theorists and economic theorists advocate expanded privileges to copy, they do so by reference to the importance of the free circulation of ideas. Lockean theorists argue that copying is justified to the extent required by the proviso that "enough, and as good" remain for others to use; the idea-expression distinction accomplishes this goal in most, though not all, cases. ${ }^{44}$ Free speech theorists link copyright's goals directly to participation in the exchange of and deliberation about ideas. ${ }^{45}$ Economic theorists assume that freedom to copy ideas

Inc. v. Nation Enters., 471 U.S. 539, 556-57 (1985); 1 DAVID NiMMER, NIMMER ON COPYRIGHT § 2.03(D) (2006).

43 Useful discussions of cultural transmission within literary theory include INFLUENCE AND INTERTEXTUALITY IN LiteraRY History (Jay Clayton \& Eric Rothstein eds., 1991); MARY OrR, InTERTEXTUality: Debates AND CONTEXTS (2003); see also Olufunmilayo B. Arewa, Copyright, Borrowing, and Unfair Use (unpublished manuscript, on file with author) (exploring implications of this view of cultural transmission for copyright's understanding of appropriate borrowing); Rotstein, supra note 22 (exploring implications for copyright's understanding of originality and infringement).

${ }^{44}$ See Gordon, supra note 2, at 1581-83 (discussing Lockean justification for exclusion of ideas); id. at 1568-72 (discussing justifications for interpreting Lockean proviso to encompass expression in certain circumstances); Hughes, supra note 2, at 313-19.

45 See Netanel, Global Arena, supra note 2, at 272-76; Netanel, Democratic Civil Society, supra note 2 at 347-64; Justin Hughes, "Recoding" Intellectual Property and Overlooked Audience Interests, 77 TEX. L. REV. 923, 975-77 \& 976 n.240 (1999) (arguing that idea-expression distinction is essential tool for enabling social dialogue). See generally Michael D. Birnhack, More or Better?: Shaping the Public Domain, in THE FUtURE OF THE PUBlic DOMAIN 59 (Lucie Guibault \& P. Bernt Hugenholtz eds., 2006). 
minimizes the "deadweight loss" that results from recognizing exclusive rights in expressive works. ${ }^{46}$ In particular, economic theorists can reconcile price discrimination with expressive competition only by relying on the free circulation of ideas as the principal vehicle for cultural transmission. ${ }^{47}$

If ideas are the basic units of cultural transmission, disputes about copyright scope become disputes about identifying those expressions that should be treated "like" ideas. The "substantial similarity" test for infringement adopts precisely this approach, separating protected from unprotected attributes based on their place within a "series of abstractions." 48 The doctrines of merger and scenes à faire, which explicitly permit copying of some expression, are justified in the same terms: they identify situations in which copying must be permitted to the extent necessary to enable the exchange of ideas. ${ }^{49}$ In cases involving musical compositions and visual works, the abstractionsbased approach creates special difficulties for judges and juries unaccustomed to parsing nonverbal expression in these terms. Judges sometimes resolve these difficulties by decreeing either infringement

46 For a representative discussion, see LANDES \& POSNER, supra note 3, at 90-97.

47 The economic account of price discrimination in oligopoly markets links price discrimination to product differentiation, which in turn is a function of differentiation in expression. For a good explanation, see Michael J. Meurer, Copyright Law and Price Discrimination, 23 CARDOZO L. REV. 55, 82-83 (2001). In considering whether price discrimination will impede or foster the creation of new works, economic theorists generally ask how the ability to price discriminate will affect price discriminators' incentives to produce works and whether it will result in optimal diffusion of those works. See id. at 94-102 (discussing disagreement on those questions). The presumed separation between (differentiated) expression and underlying idea eliminates any need to ask about the effects on others' abilities to create. But see Wagner, supra note 3 , at 1027 (arguing that because new expression always generates more ideas, granting tighter exclusive control over expression will generate even more ideas).

48 Nichols v. Universal Pictures Corp., 45 F.2d 119, 121 (2d Cir. 1930) ("Upon any work, and especially upon a play, a great number of patterns of increasing generality will fit equally well, as more and more of the incident is left out. The last may perhaps be no more than the most general statement of what the play is about, and at times might consist only of its title; but there is a point in this series of abstractions where they are no longer protected, since otherwise the playwright could prevent the use of his 'ideas,' to which, apart from their expression, his property is never extended.").

49 See, e.g., Yankee Candle Co. v. Bridgewater Candle Co., 259 F.3d 25, 35-37 (1st Cir. 2001) (applying merger doctrine); Williams v. Crichton, 84 F.3d 581, 589 (2d Cir. 1996) (applying scenes a faire doctrine); 13 NIMMER ON COPYRIGHT § 13.03[B][3], at 13-79 (2006) (discussing merger doctrine); id. \$13.03(B)(4), at 13-85 (discussing scenes à faire doctrine). 
or noninfringement on an "I know it when I see it" basis. ${ }^{50}$ What juries do is anyone's guess. In other cases, most notably those involving computer software and databases, the term "idea" also encodes a second process of abstraction. As used in copyright case law, and within copyright theory, that term denotes not only ideas per se, but also facts, processes, procedures, and methods of operation. Many of these entities are substantially less amenable to abstraction; in particular, procedures and methods of operation expressed in computer microcode and judgments about utility expressed in databases are very difficult to separate from their concrete instantiations. Calling these things "ideas" makes their concreteness easier to overlook; conversely, emphasizing their concreteness makes it easier to claim that they are not "ideas." 51 One might think that the cumulative weight of these difficulties would cast doubt on the "abstractions" heuristic. Rather than provoking a general reexamination of the notion that ideas have a separate existence, however, each of these analytical processes cements the privileged status accorded to abstraction.

Identification of "expression" divorced from animating "ideas" as the appropriate subject of ownership leads to another process of abstraction, which identifies the "work" as the locus in which rights reside. ${ }^{52}$ This process of abstraction generates broad rights that negate

50 Compare, e.g., Boisson v. Banian, Ltd., 273 F.3d 262, 271-76 (2d Cir. 2001) (finding infringement because of similarity in "total concept and feel"), with, e.g., Satava v. Lowry, 323 F.3d 805, 810-12 (9th Cir. 2003) (declining to find infringement because only ideas and standard features were copied), and Herbert Rosenthal Jewelry Corp. v. Kalpakian, 446 F.2d 738, 742 (9th Cir. 1971) (declining to find infringement because idea of jeweled bee pin merged with its expression).

51 Compare, e.g., Computer Assocs. Int'l, Inc. v. Altai, Inc., 982 F.2d 693, 708 (2d Cir. 1992) ("[T] me more efficient a set of modules are, the more closely they approximate the idea or process embodied in that particular aspect of the program's structure."), with, e.g., Lotus Dev. Corp. v. Borland Int'l, Inc., 799 F. Supp. 203, $217-$ 19 (D. Mass. 1992) (holding that particular arrangement of commands in spreadsheet menu was expression of idea of spreadsheet menu), rev'd, 49 F.3d 807, 816-17 (1st Cir. 1995) (holding that arrangement of commands in spreadsheet menu was analogous to "method for operating a VCR" and that "methods of operation' are not limited to mere abstractions"); Mitel, Inc. v. Iqtel, Inc., 124 F.3d 1366, 1373 (10th Cir. 1997) (criticizing Lotus on ground that "[17 U.S.C. §] 102(b) does not extinguish the protection accorded a particular expression of an idea merely because that expression is embodied in a method of operation at a higher level of abstraction"), and Am. Dental Ass'n v. Delta Dental Plans Ass'n, 126 F.3d 977, 979 (7th Cir. 1997) (holding that arrangement of items in taxonomy of dental procedures was copyrightable expression because it expressed particular judgments about classification).

52 On this point I am indebted to Funmi Arewa, whose description of copyrights 
defenses based on the transposition of expression into different forms. Thus it makes sense to conclude, for example, that the copyrightable expression in a film inheres in its characters in addition to the particular actions scripted for them, or that the copyrightable expression in a television show encompasses the fact that lines of dialogue were uttered in addition to the rendering of the dialogue in the context of the show. ${ }^{53}$ The initial form of creative expression becomes merely an exemplar; even expression is abstracted from itself. Concrete instantiations of works figure in this analysis primarily as sites of control; the law can focus on regulating the preparation and distribution of copies or the physical rendering of works as performances without worrying much about the form of the copying or the circumstances of the performance. Abstraction thus leads, paradoxically, toward ever more complete control of things embodying works. ${ }^{54}$ At the same time, the concept of the "work" systematically excludes forms of expression that do not fit the definition..$^{55}$

The final move in this series of abstractions relates to expression that is unowned. This content is said to be "in the public domain." In

as involving "two levels of intangibility" inspired me to think more carefully about the role of abstraction in copyright analysis. See Arewa, supra note 43, at 20; see also Rotstein, supra note 22 (criticizing construct of fixed, autonomous work).

53 See, e.g., Castle Rock Entm't v. Carol Publ'g Group, Inc., 150 F.3d 132 (2d Cir. 1998) (holding that trivia guide to Seinfeld television show infringed show's copyright); Metro-Goldwyn-Mayer, Inc. v. Am. Honda Motor Co., 900 F. Supp. 1287, 1293 (C.D. Cal. 1995) (holding that daredevil character in Honda commercial infringed copyright in "the James Bond character as expressed and delineated in Plaintiff's sixteen films" (emphasis omitted)); New Line Cinema Corp. v. Bertelsman Music Group, 693 F. Supp. 1517 (S.D.N.Y. 1988) (holding that music video featuring scary character with burned face, gloved hand with protruding razors, and raspy voice likely infringed copyright in Freddy character from Nightmare on Elm Street film series).

54 For an extended discussion of this point, see Julie E. Cohen, Overcoming Property: Does Copyright Trump Privacy?, 2002 U. ILL. J.L. TECH. \& POL'Y 375, 378-79.

55 See Newton v. Diamond, 204 F. Supp. 2d 1244, 1253-56 (C.D. Cal. 2002) (holding that copyrightable expression in musical composition consisted only of its notes and did not include scripted performance elements that author claimed as expressive), affd on other grounds, 388 F.3d 1189 (9th Cir. 2004), cert. denied, 545 U.S. 1114 (2005). See generally Anne Barron, Copyright Law and the Claims of Art, 2002 Intell. Prop. Q. 368; Anne Barron, Copyright Law's Musical Work, 15 SoC. \& LEGAL STUD. 101 (2006); Anne Barron, Introduction: Harmony or Dissonance? Copyright Concepts and Musical Practice, 15 SOC. \& LEGAL STUD. 25 (2006); Anne Barron, The Legal Properties of Film, 67 MoD. L. REV. 177 (2004); Margaret Chon, New Wine Bursting from Old Bottles: Collaborative Internet Art, Joint Works, and Entrepreneurship, 75 OR. L. REV. 257 (1996). 
recent years, the public domain has become the object of scholarly attention in its own right, but most of this effort has been devoted to determining what is in it. ${ }^{56}$ Surprisingly little scholarly effort has been devoted to determining where the public domain is. It may perhaps be objected that $I$ am being overliteral here; the public domain is a metaphor and is universally understood as such. But that objection proves too much. The public domain is a metaphor for the public's dominion, and dominion without access is a very odd sort of dominion indeed. As metaphorically constituted, the public domain is a topological impossibility: a legally constructed space to which everyone is presumed to have access. Reification of this space enables copyright jurisprudence to avoid coming to grips with the need for affirmative rights of access to unowned expression within the spaces where people actually live.

Here again, the commitment to abstraction derives from core tenets of liberal political philosophy. The liberal rationalist tradition is founded on the primacy of the autonomous, disembodied self and the possibility of transcendent knowledge. Within this vision, the concrete forms of cultural artifacts and practices do not matter very much, nor do the spaces within which cultural practices occur. The abstractions-based model of cultural production therefore is a critical conceptual underpinning of the "romantic author" model that so many copyright scholars have criticized, but it also produces broader and more systemic effects that the critique of romantic authorship does not capture. ${ }^{57}$ The abstractions-based model of cultural production tends to marginalize more concrete questions about how people use culture and produce knowledge, about the conditions that lead to creative experimentation, and about the conditions that predispose audiences to welcome such experimentation. The result is

56 See Yochai Benkler, Free as the Air to Common Use: First Amendment Constraints on Enclosure of the Public Domain, 74 N.Y.U. L. REV. 354, 360-63 (1C 39). See generally James Boyle, The Second Enclosure Movement and the Construction of the Public Domain, LAW \& CONTEMP. PROBS., Winter/Spring 2003, at 33; Lee, supra note 9; Pamela Samuelson, Challenges in Mapping the Public Domain, in THE FUTURE OF THE PUBLIC Domain 7 (Lucie Guibault \& P. Bernt Hugenholtz, eds., 2006); Pamela Samuelson, Mapping the Digital Public Domain: Threats and Opportunities, LAW \& CONTEMP. PROBS., Winter/Spring 2003, at 147.

57 Many accomplished scholars argue that the romantic author model is a root cause of distortions in copyright's understanding of cultural production. See BOYLE, supra note 23, at 51-60. See generally Arewa, supra note 43; Craig, supra note 36. Identification of root causes in culture is a tricky business. It is probably most accurate to say that the liberal rationalist tradition's commitment to abstraction undergirds the romantic author model, but that the romantic author model also reinforces the commitment to abstraction. 
a doctrinal framework that obstructs careful examination of creative processes, and makes grappling with difficult policy choices in copyright even more difficult than it ought to be.

A wide range of work in social and cultural theory provides resources with which to interrogate creative processes and practices more directly. First are a number of disciplines, ranging from musicology to literary theory to art criticism, that study processes of cultural transmission. Unfettered by copyright's precommitment to idea over expression, these fields of study have developed extensive taxonomies of expressive borrowing. ${ }^{58}$ Explicit within these taxonomies is the conclusion that the expression itself is inextricably bound up with the knowledge transmitted. Second, a diverse group of disciplines studies the importance of materiality in social and cultural practice. Some cultural theorists have focused on the body both as the inevitable mediator of cultural experience and as a site of social discipline. ${ }^{59}$ Others have explored the social construction of artifacts and practices. ${ }^{60}$ Finally, a rich and vibrant literature addresses questions of spatiality. Scholars trained in a variety of disciplines have explored the ways in which experienced space is shaped, and in which the resulting social space imposes constraints on the social and cultural processes that take shape within it. ${ }^{61}$ From the perspective of

58 See generally GORAN HERMEREN, INFLUENCE IN ART AND LITERATURE (1975); ORR, supra note 43; Allan H. PAsCo, Allusion: A literary Graft (1994); J. Peter Burkholder, The Uses of Existing Music: Musical Borrowing as a Field, 50 Notes 851 (1994). For application of theories of intertextuality to copyright, see generally Arewa, supra note 43 (literary criticism); Olufunmilayo B. Arewa, From J.C. Bach to Hip Hop: Musical Borrowing, Copyright, and Cultural Context, 84 N.C. L. REV. 547 (2006) [hereinafter Arewa, From J.C. Bach to Hip Hop] (musicology).

59 See FouCAULT, DisCIPLINE AND PUNISH, supra note 28; HARAWAY, supra note 34, at 149-70; Amelia Jones, Body ArT/Performing the Subject (1998); Carolyn Marvin, When Old Technologies Were New: Thinking About Electronic Communication in the Late Nineteenth Century 109-51 (1988); Carolyn Thomas de la Pena, The Body Electric: How Strange MaChines BuIlt the MOdern AMERICAN (2003); Martin Jay, Somaesthetics and Democracy: Dewey and Contemporary Body Art, $36 \mathrm{~J}$. AESTHETIC EDUC. 55 (2002).

60 See generally BIJKER, supra note 34; THE SOCIAL CONSTRUCTION OF TECHNOLOGICAL SYSTEMS, supra note 34; A SOCIOLOGY OF MONSTERS, supra note 34; cf. Michael J. Madison, Law as Design: Objects, Concepts, and Digital Things, 56 CASE W. RES. L. REV. 381 (2005) (exploring ways in which law participates in and accounts for construction of objects).

61 See APPAdURAI, supra note 39; FOUCAULT, DISCIPLINE AND PUNISH, supra note 28; Stephen Graham \& Simon Marvin, SPlintering URBanism: Networked

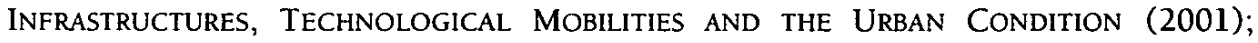
David Harvey, The Condition of Postmodernity (1990); KeVIn HeTHERINGTON, The

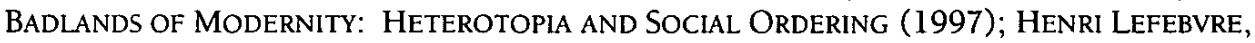


this scholarly tradition, the concept of a "public domain" in the abstract means very little. Understanding the ways in which preexisting content (including both "public domain" content and "proprietary" content) shapes creative practice requires careful consideration of the spatial distribution of cultural resources and actors.

Engagement with all of these resources is essential to fleshing out a non-teleological account of the progress that artistic and intellectual creativity enables, and that copyright is supposed to promote. Understanding the processes that generate artistic and intellectual change requires careful attention to the ways in which processes of cultural production and transmission are mediated by and through texts, objects, bodies, and spaces. In Part III, I outline the directions in which such a project might develop.

\section{DeCENTERING CREATIVITY}

How might the insights and resources of social and cultural theory help to illumine creative processes and practices? Together, they argue for an account of artistic and intellectual creativity that is decentered: that incorporates multiple contributing factors and makes none primary. This account should explore creativity as an emergent property of social and cultural systems, continually shaped by and shaping other social changes. ${ }^{62}$ Finally, an account of artistic and intellectual creativity must situate creative practice within the material and spatial realities that shape and constrain it. Here I will attempt to develop a preliminary description of creativity that satisfies these criteria. I will proceed by developing three interlinked accounts. The first begins with the self and builds outward; it explores "where creativity comes from" at the individual level. The second begins with context and builds in; it inquires how the conventions and forms of artistic and intellectual culture shape creative practice by individuals

The Production of Space (Donald Nicholson trans., 1971); The ANTHropology of Space and Place: Locating Culture (Setha M. Low \& Denise Lawrence-Zuniga eds., 2003); Saskia Sassen, Territory, Authority, Rights: From Medieval to Global Assemblages (2006); Rob Shields, Places on the Margin (1991); EdWard Soja, postmodern Geographies: The Reassertion of Space in Critical Social Theory (1988).

${ }^{62}$ On this point, I am indebted to Michael Madison, whose provocative observations about the "emergentist" character of creativity inspired me to think more carefully about the problem of specifying a cultural framework for creativity and about the elements that such a framework should contain. See Madison, supra note 26, at $1682-86$. 
and groups. The third interrogates the boundary conditions between the individual and the social, with particular regard to the essential and desirable unpredictability of creative practice. Each of these accounts is itself preliminary, and is offered as a beginning.

\section{A. Situated Users}

In accounting for creative practice by individuals, it is instructive to begin with self-reports that stress the ineffable nature of creativity. There is broad agreement among creative individuals of all types that creativity is characterized pervasively by a not knowing in advance that encompasses both inspiration and production. Yet it is possible to be far more precise both about what is not known and about what is. Neither creative inputs nor creative outputs are known in advance, but social and cultural theory tell us a great deal about the processes and practices of cultural production: about how cultural resources are encountered and used.

How do individual creators encounter unforeseen inputs, arrive at unanticipated inspiration, and generate unpredicted and unpredictable outputs? Here I want to focus on something that may seem, at first, to be a contradiction in terms: the ubiquity of constraint in the creative process. I do not mean constraint in the sense of coercion or limitation, but rather in the serse of situatedness within one's own culture. ${ }^{63}$ Situatedness does not refer to a "situation" in the prescriptive sense (i.e., one that might give rise to a legal defense or an ethical obligation), but more minimally and descriptively to the fact that individuals and groups are located within particular cultural contexts. $^{64}$ Each situated self encounters path-dependencies that shape both the content and the material forms of cultural knowledge, and thus shape creative opportunity. Recognizing situatedness does not require submerging the individual irretrievably within the social; creativity has "internal" dimensions as well as "external" ones. But what is distinct about each individual in relation to the surrounding

63 An earlier version of this argument appears in Julie E. Cohen, The Place of the User in Copyright Law, 74 FORDHAM L. REv. 347 (2005).

${ }^{64}$ More specifically, I do not mean in this paper to take any particular position about the relevance of situatedness to moral philosophy. Compare SEYLA BENHABIB, Situating the Self: Gender, Community and Postmodernism in Contemporary ETHICS (1992) (arguing that moral philosophy should recognize that individuals are situated within bodies, communities, and relational contexts), with DAVID SIMPSON, SituATEDNESS, OR Why We KeEP SAying Where We're COMING From (2002) (arguing that "the situation" is too readily invoked as substitute for efforts at understanding others and as excuse for avoiding moral responsibility). 
culture will include differences in situation and the different pathdependencies that result. ${ }^{65}$

Because everyone is a user of artistic and cultural goods first and a creator second (if at all), an account of creativity constrained by situatedness must begin with users. Elsewhere I have argued that situated users of copyrighted works appropriate preexisting cultural goods for four primary purposes. ${ }^{66}$ First, they consume cultural products, including both those that they deliberately seek out and those that they serendipitously encounter or are motivated to try for some other reason. Second, situated users appropriate cultural goods in order to communicate with one another. Third, situated users appropriate cultural goods for purposes of self-development, and such goods shape both intellectual and hedonic tastes. Finally, situated users appropriate cultural goods for purposes of creative play.

There are two important points to appreciate about these activities by situated users, which together frame a model of cultural participation that is very different than the one framed by the conventional dichotomies between author and consumer, author and imitator, author and improver, and author and critic that pervade the copyright literature. The first point is that although the activities of situated users can be listed separately for analytical purposes, in practice they often cannot be disentangled. (Here again, then, abstraction poses an epistemological danger.) Each feeds into the others in ways that are difficult to identify and impossible to predict.

The second point, which follows from situatedness, is that the cultural activities of situated users take place within a web of semantic and material entailments. One cannot simply step out of or around the resources, values, and absences within her own culture, but must negotiate one's way through them, following the pathways or "links" that connect one resource to the next. This process, which I will call "working through culture," is irreducibly contingent. It moves in patterns that are both (and sometimes simultaneously) recursive and opportunistic, and supports an understanding of creativity as relational at its core. Carys Craig argues that the model of relational feminism developed by feminist literary and political theorists enables reconstruction of "authorship" as a dialogic process consisting of "an intrapersonal dialogue (developing a form of personal narrative by drawing upon experience, situation, and critical reflection) and an

65 Cf. DEWEY, ART AS EXPERIENCE, supra note 40, at 20-35 (arguing that art emerges out of intersections between emergent self and experiences of ordinary life).

66 Cohen, supra note 63, at 370-72. 
interpersonal dialogue (drawing upon the texts and discourses around her to communicate meaning to an anticipated audience)." ${ }^{167}$ This careful, brilliant argument is (as Craig recognizes and as its scholarly antecedents demand) an argument not only about the nature of authorship but also and more fundamentally about the nature of the interaction between emergent self and evolving culture; it is an account of "where creativity comes from" that locates creativity in the process of working through culture alongside others who are always already similarly engaged. ${ }^{68}$

The process of working through culture is closely tied not only to semantic links between content but also to the spatial distribution and material forms of cultural resources. As already noted, copyright theorists have tended to offer accounts of creative processes that are highly abstract, and seem to presume access to extant cultural resources regardless of their location in space and time. For individuals situated in the real world, questions of access are inextricably bound up with the real-world distribution of artistic and cultural resources. Those resources are distributed spatially in ways that make any particular resource more or less proximate, and therefore more or less relevant, to any given individual. This spatially distributed set of cultural resources, which I have characterized as the "cultural landscape," is neither geographically discrete nor composed entirely of resources that are publicly owned; therefore, it does not map neatly to the legal category of public domain expression. ${ }^{69}$ It is defined, instead, by the ways in which artistic and intellectual goods are accessible to individuals in the spaces where they live, and by the forms of interaction with preexisting expression that are possible and permitted. The cultural landscape is what supplies the elements in culture that are experienced as common, regardless of their ownership status. Working through culture is a process of working through the cultural landscape. The distributed spatiality of cultural institutions and artifacts shapes the progression from not knowing to creative inspiration to creative production.

Working through culture also involves physical interactions among embodied users, and between embodied users and material artifacts.

67 See Craig, supra note 36 (manuscript at Part IV, on file with author).

68 Cf. Michael Dunne, InTERTEXTual Encounters in AMERICAN Fiction, Film, and POPULAR CULTURE 180 (2001) ("[N]oticing more and more intertexts is pretty much what acculturation is all about.").

69 Julie E. Cohen, Copyright, Commodification, and Culture: Locating the Public Domain, in The Future of THE Public Domain 121, 157-60 (Lucie Guibault \& P. Bernt Hugenholtz eds., 2006). 
In her influential study of the early history of "electric communication," Carolyn Marvin documented the ways in which nineteenth century Americans and Europeans used their bodies to explore the powers and limits of new technologies. ${ }^{70}$ Accounts of artistic creativity within copyright law tend to ignore the ways in which culture is similarly apprehended, assimilated, and performed through the body. Copyright scholars may be uniquely predisposed to overlook the importance of embodiedness and materiality because for most of us, the preferred medium of expression is text and the coin of reputation is the idea. The body's role in mediating consumption of artistic and intellectual goods is more evident in the performing and visual arts, for which both academic and lay reviewers alike emphasize attributes such as rhythm and flow. But embodiedness also informs the experience of literary texts. Textual works were initially recited rather than read ${ }^{71}$ and many byproducts of orality have persisted in the print era, including both enduring conventions such as poetic meter and avant garde literary expressions that self-consciously disregard established narrative conventions in favor of other, more discursive rhythms. Networked, hypertext-based environments also are experienced in terms of an embodied spatiality, characterized by distances, landmarks, and spatial juxtapositions. ${ }^{72}$

In many cases, the body plays a central role in the interpretation of and communication about cultural resources. Singing and moving to music and repeating lines of dialogue or action sequences from favorite television shows and movies are all practices that employ the body as the mediator of cultural experience. As might perhaps be expected given our occupational preoccupation with dissent, copyright scholars who have confronted the physicality of interactions with cultural artifacts have tended to emphasize direct physical manipulation of artifacts embodying others' expression in the service of "semiotic disobedience." 73 When these behaviors are situated within the broader context of embodied interaction, however, the

70 See MARvin, supra note 59, at 109-51; see also DE LA PENA, supra note 59 (arguing that development and naturalization of electric technologies were also processes of constructing "the modern self").

71 See M.T. Clanchy, From Memory to Written Record: England 1066-1307, at 266-93 (2d ed. 1993).

72 For more extended discussion of this point, see Julie E. Cohen, Cyberspace as/and Space, 107 ColuM. L. REV. 210 (Jan. 2007).

73 See Sonia K. Katyal, Semiotic Disobedience, 84 WASH. U. L. REV. 489 (2006); see also Giselle Fahimian, How the IP Guerillas Won: ${ }^{\mathrm{TM}}$ ark, Adbusters, Negativland, and the "Bullying Back" of Creative Freedom and Social Commentary, 2004 STAN. TECH. L. REV. 1 (discussing direct manipulation as form of civil disobedience). 
framework of dissent seems strained. It seems both simpler and more accurate to recognize that embodied interactions with cultural resources are ubiquitous and protean. In particular, many processes of cultural participation occur not via "consumption" in the abstract, but rather by literally inserting the self into the work, and these processes can be celebratory as well as critical. It is also worth noting that many of these activities are fundamentally group-based. A variety of performance-oriented activities, ranging from children's music recitals to karaoke to community theater, position groups gathered in physical space as important mediators of cultural knowledge.

Physical engagement with works and artifacts and direct appropriation of texts remain important as consumption and communication shade into self-constitution and creative play. In the visual and performing arts, the body becomes an indispensable tool for accessing and mastering prevailing creative conventions; imitation of the "masters" perfects technique and inscribes glossaries of form. ${ }^{74}$ As artistic techniques mature, imitation becomes dialogue, and modes of reworking become more complex, but reworking remains central. ${ }^{75}$ Regardless of artistic field or genre, creative outputs do not simply spring full-blown from the minds of their creators, but are arrived at through processes that are iterative, experimental, and hands-on. In literature and film, intergenerational dialogue manifests through the reworking of texts, including not only plots and characters but also all other forms, tropes, and conventions. ${ }^{76}$ Francesca Coppa argues that textual reworkings by mass media fans, which focus on plot and character, are forms of dramatic storytelling that reflect embodiedness, "relying on the audience's shared extratextual knowledge of sets and wardrobes, of the actors' bodies and their smiles and movements . . . to direct a living theatre in the mind." 77 Some cultural practices such as musical sampling, jazz improvisation, appropriation art, and fan

74 See generally Cornelia J. Homburg, THE COPY TuRns Original (1996) (describing central role of copying in artistic training and development).

75 See Burkholder, supra note 58, at 855 ("[A] historical development became apparent in Ives's methods of using existing music, leading from simple, commonplace types of borrowing such as modeling, settings, and variations to the more complex and individual types of his middle and later periods, such as cumulative setting, patchwork, and collage."). See generally MIEKE BAL, QUOTING CARAVAGgio: CONTEMPORARY ART, PREPOSTEROUS HiSTORY (1999).

76 See ORR, supra note 43, at 170-74. See generally HAROld BloOM, THE ANXIETY OF INFLUENCE: A THEORY OF POETRY (2d ed. 1997).

77 Francesca Coppa, Writing Bodies in Space: Media Fan Fiction as Theatrical Performance, in FAN Fiction and FAN COMMUNITIES IN THE AGE OF THE INTERNET: NEW EsSAys 225, 243 (Karen Hellekson \& Kristina Busse eds., 2006). 
fiction more directly foreground reworking. As Richard Schur describes, these are practices that invert the traditional abstractionbased hierarchy of copyright law entirely. Within these forms of cultural expression, the relation between idea and expression is not "one idea, many expressions" but rather "one expression, many ideas." 78 The key point to appreciate, however, and one that is often lost in discussions celebrating the "oppositionality" of "appropriation art," is that these modern variants are not fundamentally different from older forms of creative practice. Across the spectrum of creative practice, manipulation of preexisting texts, objects, and techniques figures centrally in processes of cultural participation.

If we return to the point from which this section began - to the not knowing that creative individuals self-report to be an indispensable element of the creative process - we see that the unknown emerges from interactions with the known via practices of juxtaposition, iteration, dialogue, and experimentation that are both conceptual and physical, and that cannot be understood as the manipulation of abstract ideas to generate linear progress. Nor can they be understood as entirely purposive. Individual creators begin with situatedness and work through culture to arrive at the unexpected. Copyright scholars should be concerned with all aspects of this process, which furnishes the means for creative expression to come into being.

\section{B. Networks of Knowledge, Networks of Practice}

Looking at creativity in systemic perspective raises additional questions for copyright scholars to consider. From a systemic perspective, artistic and irtellectual culture is most usefully understood not as a set of products, but rather as a set of interconnected, relational networks of actors, resources, and emergent creative practices. Within these networks, creative practice is shaped by all that is culture, including the demands and conventions of knowledge communities and the conventions that crystallize around particular artifacts, places, technologies, and materials. It is shaped, as well, by contests over prevailing conventions that arise both within and across cultural boundaries.

The points that I want to make here are informed substantially by methodologies in postmodernist critical theory and STS that are themselves contested. The strand of postmodernist critical theory known as deconstructionism and the strand of STS scholarship known

78 Richard Schur, Parodies of Ownership: Hip Hop Aesthetics and Intellectual Property Law 38-39 (unpublished manuscript, on file with author). 
as strict constructivist theory of technology ("SCOT") hold that texts and technologies have no fixed meanings, but rather take on meanings ascribed by their readers and users. ${ }^{79}$ These theories in turn have engendered two powerful critiques. First, both deconstructionism and SCOT have been criticized for ascribing a version of autonomy to human-generated artifacts. Second and more seriously, they have been criticized for rendering meaningful discussion about larger social and cultural processes impossible. The second critique in particular is compelling for its sheer entertainment value; at times the aversion to fixity within these scholarly literatures smacks of self-parody. It is tempting to conclude that the medium is the message. I think, though, that this is a mistake, and that legal scholars (or at least copyright scholars) have made the further mistake of being too inclined to assume that these sub-strands stand for their disciplines more generally.

I want to argue, instead, that the methodologies of critical theory and STS are most usefully understood as offering points of entry from which to explore the creation of meaning within complex cultural systems. Here the autonomy critique is a red herring; a central tenet of both critical theory and STS is that texts and technologies, and the social practices that cohere around them, are sites of evolving and contested meaning. The STS literature in particular emphasizes that a "technology" is in fact a heterogeneous assemblage of elements that together shape the particularities of its form and use. ${ }^{80}$ Over time, these assemblages can shift in response to changing practices, discourses, and institutional alignments. I want to suggest that this approach has potentially fruitful applications to the arts and intellectual pursuits that are the traditional subject matter of copyright, which emerge out of the day-to-day realities of creative practice.

If creative practice is a heterogeneous assemblage of knowledge, materials, and institutions, what are its constituent elements? With

79 A useful introduction to SCOT is Philip Brey, Social Constructivism for Philosophers of Technology: A Shopper's Guide, TECHNE, Spring/Summer 1997, at 56. On deconstructionism and the meanings of texts, see generally JACQUES DERRIDA, OF GRAMMATOLOGY (Gayatri Chakravorty Spivak trans., 1976); Jack M. Balkin, Deconstruction's Legal Career, 27 CARDOzO L. REV. 719 (2005) (describing deconstructive techniques and their problematic relation to questions of social justice).

${ }^{80}$ For examples of this approach, see generally BIJKER, supra note 34; A SOCIOLOGY OF MONSTERS, supra note 34; John Law, Technology and Heterogeneous Engineering: The Case of Portuguese Expansion, in The Social Construction of TeChNOlogical SYSTEMS, supra note 34 , at 111 . 
respect to the accumulated knowledge that animates creative practice, the Kuhnian approach to the development of scientific knowledge suggests a multi-part model of creativity. Studies of artistic culture suggest a process of iteration within established conventions punctuated by larger "representational shifts" that loosely parallels Kuhn's distinction between "normal science" and "paradigm shifts" in scientific and technical understanding. ${ }^{81}$ In "normal science" mode, creative practice is more strongly constrained by existing institutions. At moments of representational shift, this is less true. Representational shifts in artistic practice do not inevitably disrupt artistic understanding the way paradigm shifts in science do, because artistic practice does not require the same sort of grounding in fact that scientific practice does. In artistic and intellectual culture, different ways of seeing, hearing, and thinking the world can more easily coexist. Occasionally, however, representational shifts can inaugurate powerful social narratives that are more closely equivalent to paradigm shifts. A good example of the latter is Adam Smith's "invisible hand," which fundamentally changed the way Western civilization understood economics by endowing the market with an independent, metaphorically embodied existence.

Processes of artistic and intellectual production are mediated by validating institutions, which propagate the established conventions of normal science and serve as the first line of reception for (or defense against) representational shifts. Networks of cultural production create "fields" and "domains" of expertise. ${ }^{82}$ To an extent the demarcation of fields and domains is created and maintained by the entities that traditionally have been the concerns of sociology: the communities and institutions that make up "art worlds." 83 Established tastemaking institutions within art worlds play important roles in determining the fate of innovations, although new validating institutions will sometimes emerge. The Foucauldian approach to knowledge formation suggests, however, that the processes of demarcation and definition extend beyond particular institutions (museums, composers, literary critics, universities) to encompass more widely shared discursive conventions (such as ideas of authorship or distinctions between "pornography" and "art"). Both the Foucauldian approach and the Frankfurt School approach to

\footnotetext{
81 An earlier iteration of this argument appears in Cohen, supra note 69, at 14950.

82 See Bourdieu, Cultural Production, supra note 28, at 29-73; CSIKSZENTMIHALYI, supra note 40, at 36-45; GARDNER, supra note 4, at 34-40.

83 See generally BECKER, supra note 37.
} 
cultural production also direct our attention to a wider and more heterogenous assortment of validating institutions. In particular, capitalist models of cultural production and distribution exert enormous influence on the form and content of creative expression. Corporate employers in the "creative industries," corporate channels of media distribution, and providers of advertising all shape tastes and conventions in a variety of ways. ${ }^{84}$ Creative practice contests all of these processes but is also, and importantly, molded by them in matters of both form and substance. Creative practice also sits at the intersection of struggles between elite and corporate tastemakers over the division of cultural authority, which in turn affect prevailing interpretations of what counts as normal science, and for whom. ${ }^{85}$

Understanding creative processes and practices as sites of contestation with and among validating institutions also highlights the importance of more impressionistic modes of knowledge production. Bruno Latour has shown that narrative plays a central role in the social production of scientific knowledge. For example, his study of pasteurization describes a process of discursive construction that generated anthropomorphizing narratives about the microbes targeted by pasteurization; those narratives in turn shaped the public response to the new technology. ${ }^{86}$ Discursive constructions play equally

${ }^{84}$ See generally Diana Crane, The Production of Culture: MEdia AND the URBAN ARTS (1992) (adapting and extending Becker's model to accommodate mass culture). Copyright scholars have recognized aspects of this shaping, but have tended to focus more closely on aspects amenable to economic analysis or free speech analysis. See, e.g., C. Edwin Baker, Giving the Audience What It Wants, 58 OHIO ST. L.J. 311 (1997); Yochai Benkler, Intellectual Property and the Organization of Information Production, 22 INT'L REV. L. \& ECON. 81 (2002); Netanel, Democratic Civil Society, supra note 2, at 360-61; Yoo, Copyright and Product Differentiation, supra note 3.

Some argue that capitalist intermediation of media content is no longer necessary for the production of a vibrant mass culture. See, e.g., Dan Hunter \& F. Gregory Lastowka, Amateur-to-Amateur, 46 WM. \& MARY L. REV. 951 (2004). That may be right, but a cultural analysis of copyright cannot consider only what is possible. It must take into account the cultural path-dependencies that presently exist.

85 For helpful discussions of the relationships between elite and popular tastemakers, see generally Herbert Gans, POPUlar CUlture and High Culture: AN ANALYSIS \& EVALUATION OF TASTE (1999); LAWRENCE W. LEVINE, HighBROW/LOWBROW: The Emergence of Cultural Hierarchy in America (1988). For a range of perspectives on one recent controversy, see Colette Bancroft, The Gray Divide Between Popular and Literary, ST. Petersburg TImes, Jan. 24, 2004, at 1E; Harold Bloom, For the World of Letters, It's a Horror, L.A. TIMES, Sept. 19, 2003, at B13; Saul Rosenberg, In Praise of Ambiguity, JeRUSAlEM POST, Dec. 5, 2003, at 27; Stephen King, Acceptance Speech at the 2003 National Book Awards (2003), available at http://www.nationalbook.org/nbaacceptspeech_sking.html.

86 See Latour, supra note 34, at 59-110. 
important roles in shaping prevailing understandings of art, beauty, and intellectual merit. For example, the debate at the turn of the twentieth century about whether photography was an art form or a merely "technical" endeavor required the generation and embrace of new narratives about art and authorship. ${ }^{87}$ Copyright scholars have long recognized that discourses about art play a role in shaping copyright law. For example, Justice Holmes, who authored the Supreme Court's opinion recognizing copyrightable originality in circus posters, was an art collector steeped in contemporary discourses of art appreciation, and used his majority opinion for the Court to translate those discourses for a wider audience. ${ }^{88}$ At the same time, as Anne Barron has shown, copyright does not simply respond to trends in aesthetic theory; discourses within copyright also shape understandings of art. ${ }^{89}$

In addition, understanding creative processes and practices as sites of contestation raises questions about the effects of cultural boundarycrossings on the production of artistic and intellectual knowledge. In this section, I have used the term "networks" not to suggest that the study of culture is reducible to the study of network science, but instead to denote sets of interactions that are simultaneously fluid and constrained, and that lack fixed, distinct borders of their own. Networks of artistic and intellectual resources are, of course, both situated within and constitutive of culture more broadly, but these networks also can overlap other sorts of cultural boundaries, and indeed the opportunism that characterizes "working through culture" makes some such overlaps inevitable. Those boundary-crossings, in turn, may provoke struggles over every aspect of creative practice. Too often, copyright law becomes embroiled in such struggles without appreciating their wider cultural significance. As Richard Schur's detailed study of copyright's response to the hip hop aesthetic of

${ }^{87}$ See Christine Haight Farley, The Lingering Effects of Copyright's Response to the Invention of Photography, 65 U. PITT. L. REV. 385, 416-32 (2004).

88 See Diane Leenheer Zimmerman, The Story of Bleistein v. Donaldson Lithographing Company: Originality as a Vehicle for Copyright Inclusivity, in InTEllectual Property Stories 77, 94-99 (Jane C. Ginsburg \& Rochelle Cooper Dreyfuss eds., 2006); cf. Alfred C. Yen, Copyright Opinions and Aesthetic Theory, $71 \mathrm{~S}$. CAL. L. REv. 247, 266-97 (1998) (arguing that different judicial interpretations of copyright doctrine reflect implicit differences in approaches to aesthetics).

${ }_{89}$ For Anne Barron's work, see sources cited supra note 55. Cf. Michael J. Madison, Comment: Where Does Creativity Come From? And Other Stories of Copyright, 53 CASE W. RES. L. REv. 747, 759-62 (2003) (arguing that copyright law both relies on and reproduces origin stories of creativity). 
signification explores, the result may be a hardening of the cultural boundaries written into law. ${ }^{90}$

Here a word about the role of social groups is in order. Social groups play a dual role in creative processes, functioning both as users and as immediate cultural environments for individual users. Groups mediate between their own members and wider social and cultural networks more or less tightly. Within copyright law, the relative salience assigned to contributions of individuals and contributions of groups affects the designation of authorship. The points that I want to make here, however, are not about the legal assignment of authorship, but about the effects of group mediation on the substance of creative "progress." As anyone who has ever co-authored a paper or collaborated on an art project will appreciate, concrete suggestions always originate with particular individuals, but the group dynamic determines the project's overall path. This is true (in varying degrees) of all projects, not just those designated as group projects. ${ }^{91}$

Social groups also can consciously seek to channel creative practice in a variety of ways and for a variety of reasons. Along with validating institutions, social groups play important roles in determining both conceptions of artistic and intellectual merit and conceptions of the appropriate social domains of creative practice. Moreover, social groups and validating institutions may be interrelated in complex ways. In the case of indigenous or so-called "traditional" cultures, validating institution and social group are closely linked, so that conceptions of merit are closely bound up with perceptions of cultural identity. As Madhavi Sunder has described, in these circumstances contests over cultural authority can become contests over the meaning of cultural membership. ${ }^{92}$ In other cases, as the example of hip hop illustrates, the relationship between social groups and (traditional/majority) validating institutions may be more nearly disjunctive, and the contest itself may become a defining condition of cultural identity. ${ }^{93}$ In many other cultural settings, however, the relationships between social groups and validating institutions are less binary. Some social groups may exercise influence that runs orthogonally to that exercised by validating institutions, and individuals may belong to multiple groups. In these cases the

\footnotetext{
90 See Schur, supra note 78, at ch. 5 .

91 See GARDNER, supra note 4, at 43-44; SIMONTON, supra note 40, at 206-15.

92 See Sunder, Identity Politics, supra note 39, at 71-73, 91-94.

93 See Arewa, From J.C. Bach to Hip Hop, supra note 58, at 579-86.
} 
relations between identity and forms of cultural expression are more fluid, and contests over cultural authority less consuming.

Finally, because creative practice involves physical action by embodied human beings, it is shaped not only by the patterns of knowledge and discourse that crystallize around content in the abstract, but also by the patterns of behavior and discourse that crystallize around artifacts, raw materials, and social spaces. For example, the chemical and physical requirements of traditional, filmbased photography emphasize skill in "seeing," capturing, and printmaking; in digital photography, the potential for manipulation of the initial image shifts the focus to reenvisioning and altering observed reality in an infinite number of ways. ${ }^{94}$ The built environment of the concert hall, the home stereo system, the personal digital music player, and the home digital recording studio each encourages some forms of interaction with music and some techniques of composition to a greater degree than others. Processes of artistic bricolage are similarly both conceptual and physical. The genre of "world music" does not simply combine abstract compositional techniques from different musical traditions, but also combines disparate rhythms, instruments, and performance configurations. ${ }^{95}$ Judges deciding copyright disputes over music sampling have wondered why defendants did not simply make their own recordings of the desired excerpts, but the practice of sampling derives its meaning as intracultural dialogue precisely from using the original recording. ${ }^{96}$ In both of these cases and in countless others, creative practice coalesces around the expressive resources available within cultural landscapes.

Each of the dynamics described above infuses creative processes and practices with a species of path dependence characterized not by a rigid determinism but by a more fruitful complexity. To the extent that cultural artifacts and practices permit a variety of uses and interpretations, their developmental paths are never wholly within anyone's control. Both their origins and their continuing relevance are determined by negotiation and renegotiation within cultural networks.

94 See Michael Kimmelman, Walker Evans. Or Is It?, N.Y. TIMES, Aug. 25, 2006, at E27.

95 See, e.g., CheikH Lo, Lamp Fall (World Circuit/Nonesuch Records 2006); TINARIWEN, AMASSAKOUL (World Village 2004).

96 See Arewa, From J.C. Bach to Hip Hop, supra note 58, at 619-25; Schur, supra note 78 , at $8-13$. 


\section{The Play of Culture}

The foregoing discussion suggests, as it is meant to, that creative practice is substantially determined by cultural context. At the same time, it is equally clear that creative practice is not fully determined by cultural context; if it were, creative outputs would be easy to predict and we could all move on to other problems. The question thus remains: what, if anything, is it possible to say about all that is unpredictable in artistic and intellectual expression? What increases the likelihood that someone will see, hear, or think the world differently in the first place? A critical ingredient is the "play" that the networks of culture afford, including not only the extent to which they permit purposive creative experimentation, but also the extent to which they enable serendipitous access to cultural resources and facilitate unexpected juxtapositions of those resources.

Several copyright scholars have challenged the intentionalist framework that undergirds both rights theories and economic theories of copyright, arguing that artistic and intellectual innovation flow from processes of creative play. ${ }^{97}$ Research in the psychology of creativity supports this position and suggests that unstructured freedom to "see what happens" is an important determinant of creative success. ${ }^{98}$ Yet other social science research also suggests that creative play by situated users, which is at some level still a deliberately chosen activity, is not the only sort of play that matters. New pathways of artistic and intellectual exploration are opened partly by other types of serendipity that are even farther removed from individual control. Just as fields of study and domains of expertise are important determinants of creative practice, so disruption and cross-fertilization between extant fields and domains are important conditions of creative possibility. In science, some paradigm-shifting theories are generated by scientists who migrate to one field after being trained in another. ${ }^{99}$ Others, such as Einstein's theory of relativity, appear to have been stimulated by fortuitous encounters with concrete, practical problems that previous theoreticians had not considered. ${ }^{100}$ In art,

97 See Eben Moglen, Anarchism Triumphant: Free Software and the Death of Copyright, in THE COMMODIFICATION OF INFORMATION 107, 126-29 (Niva Elkin-Koren \& Neil Weinstock Netanel eds., 2002); Lange, supra note 19, at 148-51; David Lange, Reimagining the Public Domain, LAW \& CONTEMP. PrOBS., Winter/Spring 2003, at 463, 482-83.

98 See AmABILE, supra note 40, at 115-20, 231-32; CsIKSZENTMIHALYI, supra note 40, at $120-21$.

99 See SimONTON, supra note 40, at 123-25 (listing examples).

100 See Peter Galison, Einstein's Clocks, Poincaré's MaPs: Empires of Time 221 - 
representational shifts often have emerged following serendipitous encounters with artifacts, techniques, and assumptions originating within different creative traditions. ${ }^{101}$

Scholars who point to the importance of the chance encounter that yields unexpected fruit are describing both creative play and a different sort of play altogether. This sort of play, which I have called the "play of culture," has a distinct phenomenology that is not intentionalist at all, but rather is most closely analogous to what Gadamer described as "to and fro." 102 Play in the Gadamerian sense denotes a pattern that is neither entirely random nor wholly ordered. Within the realm of creative practice, the play of culture is the to-andfro in flows of artistic and cultural goods and in cultural practices of representation. Play in this sense is an essential enabling condition of cultural progress. ${ }^{103}$

If all of this seems too Zen, it is worth noting that physical scientists recognize a very similar concept. As conventionally used by physical scientists and engineers, the term "degrees of freedom" refers (in different ways) to flexibility of motion within a system or structure. As conventionally used by statisticians, the term refers to the number of independent variables that affect probability distributions. In each of these senses, degrees of freedom is said to be a measure of complexity and uncertainty with respect to the phenomenon sought to be measured or predicted. It is important to understand, however, that the term does not thereby eliminate uncertainty and unpredictability, but simply provides a convention for marking its presence. (And for that reason, "degrees of freedom" does not equal

63 (2003) (describing Einstein's work in Swiss patent office during period of intense interest in patents for coordination and synchronization of time).

101 See, e.g., Daniel Boorstin, The Creators: A History of Heroes of the IMAGINATION 384-94 (1993) (describing Brunelleschi's study of classical architecture prior to his "discovery" of linear perspective); CSIKSZENTMIHAIYI, supra note 40, at 3234 (same); Marilyn Randall, Pragmatic Plagiarism: Authorship, Profit, and Power 238-40 (2001) (discussing emergence of "African novel"); Paul E. Geller, Hiroshige vs. Van Gogh: Resolving the Dilemma of Copyright Scope in Remedying Infringement, $46 \mathrm{~J}$. COPYRIGHT SOC'Y U.S.A. 39 (1998) (discussing impressionist painters' appropriation of compositional and stylistic elements from Hiroshige woodcuts).

102 See HANS-Georg Gadamer, TRUTH AND METHOD 102-10 (Joel Weinsheimer \& Donald G. Marshall trans., $2 \mathrm{~d}$ rev. ed. 2004); see also Cohen, supra note 63, at 371-73.

103 For arguments in a similar vein, see generally Paul Edward Geller, Must Copyright Be For Ever Caught Between Marketplace and Authorship Norms?, in OF AUTHORS AND ORIGINS 159, 192-98 (Brad Sherman \& Alain Strowel eds., 1994) (relating progress to "sign wealth"); Michael J. Madison, Complexity and Copyright in Contradiction, 18 CARDOZO ARTS \& ENT. L.J. 125, 145-58 (2000) (relating progress to complexity in aesthetic environment). 
"probability," which quantifies and predicts the behavior of actors or systems. Although the two concepts are often used in tandem, they are distinct.)

Together, the play of culture and the processes of creative play that it sustains are what prevent established ways of seeing, hearing, and thinking the world from becoming calcified. Logically and chronologically antecedent to the creative play performed by individuals and groups, the play of culture supplies the unexpected inputs to creative processes, fuels serendipitous consumption by situated users, and inclines audiences toward the new. The chance encounters it generates are sources of dissonance, provocation, meaning, and unexpected beauty. Creative play by situated users exploits both the practices and conventions within established networks and the chance connections that the play of culture provides.

\section{ENGINEERING CREATIVITY: LAW AND CULTURE}

What are the consequences of understanding creative processes in the way that I have just described? Although the model elaborated in Part III is (ironically) quite abstract, this approach to theorizing the creative process has some very direct implications for copyright policy and doctrine. Decentering creativity disrupts the tight linkage between copyright and creativity that has come to dominate public debate about copyright issues, and that pervades legislative and policy processes. This, in turn, enables an account of the oft-invoked "copyright balance" that emphasizes the process of working through culture and the importance of play within cultural landscapes. This twofold reframing dictates a very different approach to questions of optimal copyright scope. At the same time, it underscores the connections between copyright, cultural progress, and social justice.

Lobbyists for the copyright industries are in the habit of asserting that copyright is the single most critical prerequisite for a vibrant artistic and intellectual culture. Some of this is theater driven by political expediency. No one wants to be against creativity, and if copyright equals creativity then no one wants to be against copyright. Yet beneath the rhetoric, both copyright lawyers and copyright scholars tend to assume that copyright law is centrally important in stimulating a high level of creativity. Since copyright theory and jurisprudence persistently devalue the role of context in shaping culture, that assumption is unsurprising. The tight linkage between copyright and creativity, however, both fuels romantic author narratives and justifies drawing firm distinctions between authors, on 
the one hand, and consumers, imitators, and improvers on the other. Those distinctions dominate the current landscape of copyright law; they undergird broad rights to control copies, public renderings, and derivations of copyrighted works and expansive readings of the rules that create liability for technology providers.

Decentering creativity challenges the widespread assumption about nature and direction of copyright's influence on creativity in two ways. First and most obviously, it tends to suggest a much more modest conception of the role that copyright plays in stimulating creative processes and practices. Copyright fulfills some important economic functions (of which more shortly), and therefore plays an important role in organizing cultural production, but it is hardly ever the direct cause of a representational shift in creative practice, nor does it appear to play a direct role in motivating much that is normal science. Scholars who ask how deploying copyright might stimulate creativity (as opposed to production) are asking the wrong question. Neither creative inspiration nor the creative outputs that follow from it are so easily engineered.

Questions remain, however, about the extent to which the contextual factors that are more important in stimulating creativity are amenable to social engineering. Arguably, the dynamic that I have described would exist in any social and economic system that is sufficiently complex. And if creativity is not especially amenable to social engineering, perhaps both those whose primary concern is social engineering and those whose primary concern is strong copyright can simply take it as a given. At the very least, then, one might posit that strong copyright does no harm. Put differently, if copyright is not the most important factor in stimulating creativity, it still may be the most important factor within our control. If copyright serves other important functions, such as the organization of private cultural production and the distribution of artistic and intellectual goods, perhaps strong copyright is good policy.

Here the decentered model of creativity makes its second contribution: it provides a firmer foundation for arguments about the systemic harms that a regime of copyright can produce. Critics of copyright maximalism have long argued that overly rigid control of access to and manipulation of cultural goods stifles artistic and cultural innovation, and a growing body of anecdotal evidence suggests that copyright's "permission culture" does exert a substantial constraining influence on creative practice. ${ }^{104}$ Similarly, research in

104 See Suntrust Bank v. Houghton Mifflin Co., 268 F.3d 1257, 1282 (11th Cir. 
the psychology of creativity suggests that attempts to impose a rigid structure on the creative process quickly become counterproductive, and that the success of the creative process hinges in part on the ability to avoid externally imposed distractions. ${ }^{105}$ A model of creativity grounded in the methods of social and cultural theory supplies both a rigorous analytical underpinning for those arguments and observations and a discourse in which to frame them. Within this framework, a regime of copyright that aims to promote cultural progress must be assessed based on its effects on creative practice by situated users, and on the extent to which it renders elements of the cultural landscape more or less accessible. And within this framework, those who advocate more limited copyright can be "for" rather than "against" creativity.

What legal regime, though, does the decentered model of copyright recommend? It might be argued that copyright and play are definitionally incompatible. There is an inevitable tension between social theorists' emphasis on mobility, emergence, and decentering and the legal system's need for fixity, clarity, and predictability. Some theorists from both sides of the law-social science divide have argued that legal recognition of particular kinds of claims - to specific forms of cultural property, or to particular formulations of human rights itself works a form of imperialism, in which the law's need for doctrinal and definitional certainty is inimical to the demands of emergent social processes. ${ }^{106}$ To an important extent, though, this social science critique of law's possibility ignores its own most powerful disciplinary insight: law is not separate from social systems. As Naomi Mezey has described, the relationship between "law" and "culture" is an interdependent one characterized by cycles of

2001) (Marcus, J., concurring) (describing testimony of author Pat Conroy about restrictions that Margaret Mitchell estate sought to impose on would-be writers of "official" sequel to Gone with the Wind); Patricia Aufderheide \& PETER Jaszi, Untold Stories: Creative Consequences of the Rights Clearance Culture for DOCUMENTARY FILMMAKERS 29-40 (2004), http://www.centerforsocialmedia.org/rock/ index/htm. See generally Marjorie Heins \& Tricia BeckLes, Wili. Fair Use Survive? Free Expression in the Age of Copyright Control (2005); LaWrenCe lessig, Free Culture: How Big Media Uses Technology and the Law to Lock Down Culture AND CONTROL CREATIVITY (2004); Illegal Art, Freedom of Expression in the Corporate Agency, http://www.illegal-art.org/ (last visited Feb. 9, 2007).

105 See AMABILE, supra note 40, at 115-20, 231-32; CSIKSZENTMIHALYI, supra note 40, at $120-21$.

106 See Michael F. Brown, Who Owns Native Culture? 209-27 (2003); Alexander A. Bauer, Definitional Anxieties, ANTHropology News, Dec. 2005, at 27; Annelise Riles, Anthropology, Human Rights, and Legal Knowledge: Culture in the Iron Cage, AM. ANTHROPOLOGIST, Mar. 2006, at 52. 
definition, slippage, and redefinition. ${ }^{107}$ Within this general pattern, law and culture evolve together; the fixity that law imposes within culture is a matter of degree and may be a defensible means of pursuing other social goals that are themselves evolving.

In designing a good system of copyright, then, we also must consider the other social goals that a system of copyright serves. Here economic theorists' emphasis on the production and distribution of cultural goods becomes important and can be restated more accurately: copyright is a means of creating economic fixity, and thus predictability, in the organization of cultural production. Control of copying, manipulation, and derivation enables the organization of entire sectors of economic activity in ways that produce a variety of concrete benefits, ranging from jobs and exports to an independent expressive sector to cultural "solidarity goods." 108 Those are desirable goods; a society characterized by complete lack of economic certainty would be unstable, state control of cultural production would be undesirable, and a culture without shared expressive referents would be far less enjoyable. But these arguments too have been pushed to extremes in the copyright wars. Lobbyists for the copyright industries argue that because copyright enables economic and cultural productivity, truncating copyright entitlements would be disastrous not only for their employers, but also for the country more generally. ${ }^{109}$ Neither conclusion follows. In the real world, which is the world that creative communities have always inhabited, play and economic stability are not mutually exclusive. Shared expressive referents predate mass culture, and mass culture benefits from "an interdependence, even a circulation, between mass and popular culture. Popular culture makes use of the mass cultural resources that capitalism provides, and mass culture often co-opts and markets pop cultural practices." ${ }^{10}$ And it is well recognized that economic fixity is not an unmitigated good.

107 See Naomi Mezey, Law as Culture, 13 YALEJ.L. \& HuMan. 35, $57-66$ (2001).

108 See Netanel, Democratic Civil Society, supra note 2, at 352-62; see also Guy Pessach, Copyright Law as a Silencing Restriction on Noninfringing Materials: Unveiling the Scope of Copyright's Diversity Externalities, 76 S. CAL. L. REv. 1067, 1083-91 (2003) (highlighting importance of solidarity goods but arguing that mass commercial culture exerts undesirable influence on content of such goods). See generally TYLER COWEN, In Praise of Commercial Culture (1998).

109 See also Hughes, supra note 45, at 926 (arguing that audiences for copyrighted works benefit from cultural stability).

110 Naomi Mezey \& Mark C. Niles, Screening the Law: Ideology and Law in American Popular Culture, 28 ColuM. J.L. \& ARTs 91, 99 (2005). 
It is therefore correct to say that copyright requires a balancing act, but the decentered model of creativity prompts us to redescribe what copyright balances. What is required is not a balance between present authors and the abstract "public," nor between valuable entitlement and ephemeral "deadweight loss," both formulations that encourage would-be balancers to equate relative concreteness with relative importance. Balance also does not refer merely to a process by which the claims of competing interest groups are aired en route to striking a deal. As Robert Burrell and Allison Coleman have trenchantly observed, references to balancing in copyright rhetoric contain a "semantic ambiguity" that results in slippage between notions of balance as process and notions of balance as correct result. ${ }^{111}$ The notion of balance that I mean to invoke is substantive, and concerns the ways in which copyright's goal of creating economic fixity must accommodate its mission to foster cultural play.

Economic analysis can help us to understand some of the considerations relevant to the balance between economic fixity and cultural mobility, but both valuation and incommensurability problems prevent a comprehensive summing of the relevant costs and benefits. Modeling the benefits of artistic and intellectual flux is hard to do, and comparing those benefits with the more tangible, predictable gains from existing models of creative production is even harder. The emphasis on creative destruction now popular among copyright scholars invokes an historical theory, not an economic theorem. ${ }^{112}$ As Karl Polanyi reminded us, moreover, creative destruction is nicest for those who do not have to undergo it. ${ }^{113}$ It is hardly surprising, then, that economic theorists cannot agree on how to model the optimal regime for promoting "improvements." No one is against creativity, but that apparent unanimity conceals rather large disagreements about how wholeheartedly and unreservedly we are for it. Modeling the opportunity costs of cultural fixity is equally difficult. Although we can say with some confidence that costs affect individual behavior, it is hard to know the cumulative effect of those costs on

i1 See Robert Burrell \& Allison Coleman, Copyright Exceptions: The Digital IMPACT 188-91 (2005).

112 See, e.g., Raymond Shih Ray Ku, The Creative Destruction of Copyright: Napster and the New Economics of Digital Technology, 69 U. CHI. L. REv. 263, 294-311 (2002) (arguing that copyright is not needed to induce either creation or distribution in

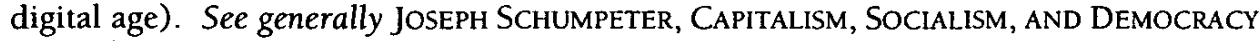
81-86 (1950) (coining term and explaining its significance).

113 See Karl Polanyi, The Great Transformation: The Political and Economic ORIGINS OF OUR TIME 37-42, 77-102 (1944). 
unknown future behavior. To the extent that economic modeling focuses on what is known (or assumed) about benefits and costs, moreover, it tends to crowd out the unknown and unpredictable, with the result that play remains a peripheral consideration when it should be central.

To grapple with these problems, a larger toolkit and a different attitude toward social engineering are required. Methodologically, the distinction I am trying to draw is one between a social theory of creativity that embraces an eclectic range of methods, including economic methods, and an economic model of creativity that has room only for its own methods, and that consequently distorts in predictable and predictably damaging ways. Substantively, the distinction is one between deploying known cost-benefit calculations in an attempt to generate predictable results and deliberately leaving room for unpredictable results to emerge. Creativity requires breathing room, and thrives on play in the system of culture. This suggests powerfully that copyright entitlements should be narrow and clearly incomplete, and that the scope for individual experimentation should be generous. It suggests, as well, that courts deciding infringement cases should not attempt to close gaps in the structure of copyright out of misplaced sympathy to current rightholders, but instead should exercise self-restraint.

Rights theories, meanwhile, can help us to articulate some of the aspirations that a good regime of copyright should promote, but furthering those aspirations requires moving beyond abstract ideals to concrete guarantees. Yochai Benkler powerfully advances the cause of a robust vision of liberal humanism that "is concerned first and foremost with the claims of human beings as human beings." 114 Within that vision, it makes sense to talk about liberal ideals of autonomy and self-determination and to understand those ideals as bound up with a larger commitment to human flourishing. But a commitment to human flourishing also requires more direct engagement with the patterns of cultural progress and with the material and spatial realities of cultural processes. Autonomy is exercised, and self-determination pursued, by working through culture. Laws granting rights in artistic and intellectual expression should be designed with that process in mind. And, as Madhavi Sunder reminds us, culture is not an obstacle that must be transcended en route to self-determination, but a medium of self-

114 BENKLER, supra note 7, at 19. 
determination in its own right. ${ }^{115}$ Copyright should promote participation in culture for the sake of culture as well as for the sake of political freedom.

By foregrounding the material and spatial realities of cultural processes, the decentered model of creativity simultaneously provides a firmer foundation for articulating the structural connections between copyright, cultural play, and social justice. Simply put, overly broad copyright exacerbates the structural effects of unequal access to cultural resources by placing additional obstacles in the path to cultural participation. Narrower copyright avoids this risk in some cases, and also works in the opposite direction. In removing obstacles to cultural participation, narrower copyright broadens and deepens a society's capacity for cultural progress. ${ }^{116}$ Economically oriented intellectual property theorists are apt to characterize (properly calibrated) intellectual property protection as creating a virtuous circle of creation and investment. We can think of the decentered model of creativity as describing a virtuous circle of a different sort, in which greater allowance for play in access to and use of cultural resources promotes substantive equality and equality multiplies the possibilities for the progress of a vibrant collective culture.

\section{COPYRIGHT FOR CREATIVITY: AN EXAMPLE}

What, finally, can rethinking the relationship between copyright and creativity teach us about the analysis of specific problems in copyright law and policy? The argument that I have developed suggests an approach grounded in careful, contextualized analysis and skeptical of arguments from abstract virtues like liberty and desert. This approach would resist broad formulations of protected rights and prohibited actions, and instead would attempt to divide entitlements more clearly and equitably between authors and others via pragmatic line-drawing. Here is one example of the way in which that process might work.

In recent years, retellings of copyrighted fictional works have generated some high-profile copyright controversies. These retellings have appeared in a variety of contexts, ranging from commercially marketed sequels to widely distributed but noncommercial Internet fan fiction. In The Wind Done Gone, Alice Randall related the story of Margaret Mitchell's Gone with the Wind in the voice of a new character, the slave half-sister of Southern belle Scarlett O'Hara. When the

\footnotetext{
115 Sunder, supra note 14 , at 328-332.

116 See BENKIER, supra note 7, at 317-28 (peer production of knowledge goods); Chon, supra note 14, at 2893-2900 (access to educational materials).
} 
Mitchell estate sued to block publication, Randall's publisher successfully defended her book as a fair use parody of Mitchell's. ${ }^{117}$ Every day, on thousands of Internet sites, fans of popular television shows, movies, and books share their own retellings of those works. Fan fiction runs the gamut from juvenile to sophisticated. Some fans seek to create narratives that are continuous with those in the original works, but many do not. ${ }^{118}$ While some copyright owners have tolerated and even encouraged fan retellings, many have tried to shut down fan sites. As Sonia Katyal has documented, so-called "slash" narratives, which imagine male-on-male sexual relationships between existing characters, have proved particularly unpopular with copyright owners. ${ }^{119}$ Within the decentered model of creativity, before deciding on the appropriate copyright treatment of these and other retellings one would want to know more about the different contexts in which they appear and the cultural functions that they serve. But the standard approaches to this problem within copyright law and copyright theory do not ask these questions at all.

Doctrinally, copyright analysis of a retelling begins by asking whether the retelling is a "derivative work." Since that abstract, general category is defined so broadly as to include any recasting of the copyrighted original, ${ }^{120}$ the threshold case for infringement is easy to make. The analysis then shifts to the question of fair use, and has come to depend principally on two factors. First, courts inquire whether the retelling is "transformative"; to satisfy this criterion, the work must contain a discernible element of critical commentary. ${ }^{121}$ Second, they ask whether and how the retelling will affect the market for the underlying work, including the licensing market for authorized sequels. ${ }^{122}$ As several perceptive commentators have noted, within the framework of literary theory this test is broad enough to encompass almost anything; every retelling comments on the original in one way or another. ${ }^{123}$ Courts, however, have resisted arguments of this sort,

\footnotetext{
117 SunTrust Bank v. Houghton Mifflin Co., 268 F.3d 1257 (11 th Cir. 2001).

118 For descriptions, see Sonia K. Katyal, Performance, Property, and the Slashing of Gender in Fan Fiction, 14 AM. U. J. GENDER SOC. POL'y \& L. 461, 463-64, 483-87 (2006); Rebecca Tushnet, Payment in Credit: Copyright Law and Subcultural Creativity, 70 LaW \& CONTEMP. Probs. (forthcoming Winter/Spring 2007) (manuscript at Pt. II, on file with the author).

119 Katyal, supra note 118 , at 463-64.

120 See 17 U.S.C. § 101 (2005).

121 See Campbell v. Acuff-Rose Music, Inc., 510 U.S. 569, 579-83 (1994).

122 See id. at 590-93; SunTrust Bank, 268 F.3d at 1273-76.

123 See Katyal, supra note 118, at 474-75; Tushnet, supra note 118 (manuscript at text accompanying n.6).
} 
both because they have no obvious stopping point and because they appear to negate the licensing inquiry. Instead, they have insisted that claimed fair uses be more clearly identifiable with what Rebecca Tushnet characterizes as the First Amendment value of dissent. ${ }^{124}$

Within both economic and rights theories of copyright, insistence on determinate rules derived from abstract first principles reinforces the structure of the doctrinal analysis. For most economic theorists of copyright, granting copyright owners control over the preparation and exploitation of derivative works is broadly justified as a means of perfecting market signals about the optimal "level" and "direction" of investment in creative expression, and exceptions should be confined to the few cases in which licensing could not reasonably be expected to occur. ${ }^{125}$ In general, those scholars tend to think that the exceptional cases can be identified by distinguishing between criticism and mere substitution; "criticism" is unlikely to be licensed, so it is criticism that fair use should protect. Some economically oriented scholars think that fair use should encompass a broader range of cases in which "spillovers" result in public benefit and are likely to prevent efficient bargains. ${ }^{126}$ The spillovers argument, however, provides no determinate standard for identifying those cases; arguably, any unauthorized sequel that is good would generate spillovers, but those theorists seem generally unwilling to go that far. In the real world, this objection should not be fatal; indeterminacy does not rule out pragmatic policymaking. Within the epistemological confines of

124 See Rebecca Tushnet, Copy This Essay: How Fair Use Doctrine Harms Free Speech and How Copying Serves It, 114 YALE L.J. 535, 549-52 (2004). Compare, e.g., SunTrust Bank, 268 F.3d at 1270 (characterizing Alice Randall's work as "principally and purposefully a critical statement that seeks to rebut and destroy the perspective, judgments, and mythology of [Gone With the Wind]"), and Mattel, Inc. v. Walking Mountain Prods., 353 F.3d 792, 802 (9th Cir. 2003) (observing that photographs depicting Barbie as endangered by kitchen appliances or in "sexually suggestive" poses and settings "parody Barbie and everything Mattel's doll has come to signify"), with, e.g., Dr. Seuss Enters. v. Penguin Books USA, Inc., 109 F.3d 1394, 1401 (9th Cir. 1997) (holding that illustrated guide to O.J. Simpson murder trial in style of Dr. Seuss was not fair use because it used style only as vehicle to comment on something else), and Rogers v. Koons, 960 F.2d 301, 306-11 (2d Cir. 1992) (holding that sculpted rendition of photograph of two people holding litter of puppies, characterized by sculptor as emphasizing photograph's "banality," was not fair use because no critical commentary was discernible).

125 See Paul Goldstein, Derivative Rights and Derivative Works in Copyright, $30 \mathrm{~J}$. COPYRIGHT SOC'Y U.S.A. 209, 227 (1983); see also GOLDSTEIN, supra note 3, at 200-01; LANDES \& POSNER, supra note 3, at 110-12.

126 See Lemley, Economics of Improvement, supra note 3, at 1056-58; Brett $\mathrm{M}$. Frischmann \& Mark A. Lemley, Spillovers, 107 CoLUM. L. REV. 257 (2007). 
economic analysis of law, however, generalized reliance on "externalities" tends to be perceived as signaling a lack of analytical rigor. The problem, in other words, is not the argument itself, but rather these theorists' inability to provide an answer in the terms that their discipline values most highly.

Rights theorists apply different principles but reach the same results. Like economic theorists who emphasize spillovers, rights theorists who emphasize expressive liberty tend to favor a more expansive interpretation of what should count as transformative critical commentary. Once again, however, without the First Amendment value of dissent to serve as a guideline, this approach does not provide a determinate test for distinguishing between permissible and impermissible retellings, and once again this is a problem for the theory taken on its own terms. Those who emphasize Lockean property rights tend to feel that principles of self-ownership justify granting copyright owners control over derivations except (again) when free speech norms of dissent come into play. Within Lockean theory, the basis for the distinction is not market failure but a deontological principle of need; for most such theorists, this tends to suggest that fair use should excuse only those retellings that can be classified as parodies. ${ }^{127}$

Wendy Gordon's recent effort to justify a broader range of unauthorized retellings within the framework of Lockean property rights is an extraordinary and thought-provoking effort that ends up demonstrating most powerfully the need for a different framework. Gordon seeks to expand the scope of the need-based justification for fair use based on a theory of emotive "capture." 128 On this theory, expressive works can take such strong hold of the imagination that others must engage in retellings to regain their own self-ownership. That rule would excuse a much wider variety of borrowing than the "parody-satire distinction" or the criterion of transformative critical commentary, but Gordon wants to argue that the rubric of need encompasses nearly all such borrowing. She argues, therefore, that need arises because artists "integrate the prior work into themselves." 129 But this is not an argument about Lockean need at all;

127 Cf. Campbell v. Acuff-Rose Music, Inc., 510 U.S. 569, 580-81 (1994) ("Parody needs to mimic an original to make its point, and so has some claim to use the creation of its victim's (or collective victims') imagination, whereas satire can stand on its own two feet and so requires justification for the very act of borrowing.").

128 See Wendy J. Gordon, Render Copyright Unto Caesar: On Taking Incentives Seriously, 71 U. CHI. L. REV. 75, 81-87 (2004).

129 Id. at 84. 
it is not an argument that distinguishes between owned and common. It is an argument about social need: about the inseparability of idea and expression and the cumulative, iterative, interactive nature of creative practice. In an effort to work around this problem in a way that avoids harm to intellectual laborers, Gordon suggests that courts should apply liability rules to some retellings, but only to those that occur in contexts where "pre-use negotiation or licensing" is expected. ${ }^{130}$ That argument comports with the Lockean no-harm principle, but it is no longer an argument that concerns itself with the nature of the borrowing. As others have observed, moreover, a compensation requirement might have the perverse effect of suppressing those retellings that map most closely to the dissent trope. Even though Randall distributed her work in the context of mass market commercial publishing, where licensing has become the norm, she most likely would not have wanted to enrich the Mitchell estate. ${ }^{131}$

Under the decentered model of creativity, a fair use analysis of retellings would abandon both the current criterion of "transformative" critical commentary and the search for a determinate, objectively derived standard of permissibility, and instead would consider a more open-ended set of questions about the role of retellings in the process of working through culture. Under this approach, fan fiction of all genres would be categorically exempt from a finding of infringement. For better or worse, fictional works are important components of collective cultural landscapes, and anyone who has an interest in the content of culture and the direction of cultural progress - which is to say, anyone with a pulse - must engage with what is already there. Personal dialogues with collective culture begin in childhood, when children imagine themselves into favorite fictional worlds or when they conclude, because they do not see characters resembling themselves, that those worlds have no place for them. ${ }^{132}$ Writing fan narratives carries forward these personal dialogues, and sharing them enables broader collective dialogues to take shape. Fan fiction communities thus serve as important nodes for the ongoing interchange between mass and popular culture, and this is

130 Id. at 89-91; see also Jed Rubenfeld, The Freedom of Imagination: Copyright's Constitutionality, 112 YALE L.J. 1, 55-58 (2002) (offering similar proposal).

131 See David McGowan, Why the First Amendment Cannot Dictate Copyright Policy, 65 U. PITT. L. REV. 281, 330-31 (2004).

132 See Anupam Chander \& Madhavi Sunder, Everyone's a Superhero: A Cultural Theory of "Mary Sue" Fan Fiction as Fair Use, 95 CaL. L. REv. (forthcoming Feb. 2007); see also Dorothy Allison, Skin: Talking About Sex, Class and Literature 165-81 (1994). 
so whether the point is to transport the writer into a fictional world while leaving that world otherwise intact or to issue a broader challenge to the terms on which the world is constructed. And fan fiction does not threaten the economic value of the copyrighted work at all; if anything, the reverse is true. ${ }^{133}$ In the case of fan fiction, then, there is no interest in economic stability to be balanced.

Commercially distributed retellings, meanwhile, would require more careful differentiation. It seems entirely reasonable to think that a copyright should protect the right to issue authorized sequels (albeit, perhaps, for a much more limited period of time). The economic stability that copyright guarantees to authors and publishers should include the right to develop and market continuations of the story that the author wants to tell. But it should not include, and need not include, the right to forbid the stories others want to tell. The justifications for allowing others to develop and market their stories are compelling and extend far beyond the framework elaborated by current fair use doctrine. Retellings are an indispensable mechanism of cultural progress. Some critically acclaimed authors have retold their own stories, ${ }^{134}$ but many more have retold the stories of others. Over time, the storehouses of myth become replenished by the creations of mass culture. Indiana Jones supplants Ulysses and the story of Ross and Rachel displaces the legend of Pyramus and Thisbe. Even so, a rule cannot be laid down that would excommunicate the novels of the next Joyce or the plays of the next Shakespeare. ${ }^{135}$ For exactly that reason, although fan fiction is a seedbed for retellings, meaningful access to the cultural landscape requires more than just freedom to create fan narratives. As Tushnet argues, a rule segregating all unauthorized retellings in nonmarket spaces would deny the essential hybridity of cultural processes. ${ }^{136}$ The case of commercial retellings, then, requires a pragmatic compromise, in which copyright prohibits only those commercially distributed retellings that attempt to inhabit the author's voice.

That analysis suggests, however, that more comprehensive doctrinal revision is in order. Fair use is the most important determinant of copyright breadth only if one takes current baselines of infringement as given; if copyright were narrower in the first place, fair use would

\footnotetext{
133 See Katyal, supra note 118 , at 508.

134 See LaWrence DurRell, Justine (1957); LAWRence DurRell, BalthaZar (1958); LaWrence Durrell, Mountolive (1959); LAWrenCe Durrell, Clea (1960).

135 Cf. Bleistein v. Donaldson Lithographing Co., 188 U.S. 239, 251 (1903) ("A rule cannot be laid down that would excommunicate the paintings of Degas.").

136 See Tushnet, supra note 118 (manuscript at Part V).
} 
have less work to do. It seems far more productive to acknowledge that the foundational "derivative work" abstraction is both extraordinarily broad and singularly unhelpful in determining how much control over retellings we might want to grant. A copyright regime concerned more directly with the balance between economic fixity and cultural progress would seek to replace broad, allencompassing statutory provisions and generous judicially created tests for infringement with narrower, more clearly delimited formulations covering different kinds of derivations. ${ }^{137}$ In this example, the replacement provision would grant copyright owners of literary and audiovisual works the right to prepare for commercial exploitation sequels of the original work. It would exclude the preparation of sequels for noncommercial use, and would define "sequels" to include only those works continuing the narrative voice established by the original. That definition, in turn, would require judicial interpretation, but a legislative history packed with examples of real and hypothetical retellings - "If Harry Potter survives his final year at Hogwarts, only J.K. Rowling gets to sell an eighth Harry Potter novel, but anyone can write and sell any other character's story, or a new character's story" - could put flesh on the bare bones of the statutory definition, and teach courts new norms of restraint.

As this example illustrates, there are points of entry within existing copyright doctrine for a decentered model of creativity, but if taken seriously the model demands far more sweeping changes to the fabric of copyright law and policy. To be clear, in offering the rule described above I do not claim either that it is perfect or that it is logically derivable from some determinate source of bright line rules that both economic theorists and rights theorists have overlooked. My argument, instead, is simply this: in cases where interests in economic stability and cultural mobility must be balanced, an examination of creative practice informed by social and cultural theory can indicate the appropriate content of pragmatic compromises designed to foster cultural mobility. Such compromises will be more effective if they operate at copyright's baseline in the form of bright-line rules. This

137 For other suggestions in this general vein, see Cohen, supra note 69, at 162-64; Geller, supra note 103, at 192-98; JESSICA LITMAN, DIGITAL COPYRIGHT 180-82 (2001); Ann Bartow, Copyrights and Creative Copying, 1 U. OTTAWA L. \& TECH. J. 75, 92-103 (2003-04); Cohen, supra note 63, at 373-74; Lydia Pallas Loren, The Changing Nature of Derivative Works in the Face of New Technologies, 4 J. SMALL \& EMERGing BuS. L. 57, 76-92 (2000); Ruth Okediji, Givers, Takers, and Other Kinds of Users: A Fair Use Doctrine for Cyberspace, 53 FLA. L. REV. 107, 140-43 (2001); Jessica Litman, Lawful Personal Use (Univ. of Mich. John M. Olin Ctr. for Law \& Econ. Working Paper Series, Paper No. 06-004, 2006), available at http://ssrn.com/abstract $=926575$. 
makes bright line rules superior even though they are imperfect. Linedrawing inevitably leaves a few cases on the "wrong" sides of lines, and line-drawing in copyright also cuts against deeply ingrained instincts which urge that latitude for "imitators" is unjust to authors and owners. Yet a copyright regime capable of reaching beyond those instincts would be truer to its stated goals than the one we now have. The result of such a process would be a copyright regime of more modest reach but ultimately more expansive ambition. 
HeinOnline -- 40 U.C. Davis L. Rev. 1206 2006-2007 